\title{
The Upper Jordan River Algal Communities are Evidence of Long-Term Climatic and Anthropogenic Impacts
}

\author{
Sophia S. Barinova*, Eviatar Nevo \\ Institute of Evolution, University of Haifa, Mount Carmel, Israel \\ E-mail: barinova@research.haifa.ac.il,nevo@research.haifa.ac.il \\ Received March 25, 2010; revised April 23, 2010; accepted May 6, 2010
}

\begin{abstract}
Spatial and temporal algal diversity changes were studied in the major drinking water source of Israel - the Upper Jordan River. During 2006-2009, we found 232 species and infraspecies of algae and cyanobacteria: 85 of which were new for the Upper Jordan River Basin including three new for Israel. During many years of study of the Upper Jordan River, we collected information for the database of algal diversity. Historical analysis from 1883 to 2009 shows fluctuation of the whole algal diversity. Environmental indicator species show peaks in 1951, 1965, 1978, and 2009. Salinity impact was found in 1938 and 2000; acidification was detected in 1938, 1996, and 2000, and organic pollution, in 1996. Therefore, we can conclude that 1938, 1996, and 2000 were critical periods for the Upper Jordan River ecosystem. Indication of the trophic status shows stress of organic pollution since the 1970s, which was marked by dramatic increases in eutraphentic and hypereutraphentic species. The present analysis shows three peaks in the fluctuation in diversity throughout the river canal, which correlated with the organic pollution impact from the Masade village effluence in the middle reaches and near Lake Kinneret. Pollution was significant in rainy winters and stimulated species diversity development. The different approaches in comparing diversity in each river of the Upper Jordan Basin revealed that hydrology is a major regulating factor in species composition of the algal communities, which were formed under the influence of regional climatic factors. Therefore, the river can be highlighted as a natural system with high buffering and a self-purification capacity at the present time.
\end{abstract}

Keywords: Algal Communities, Bio-Indication, Climate Change, Comparative Floristic, Israel, Jordan River

\section{Introduction}

Biodiversity of algal communities in the Upper Jordan River formed according to natural climatic and anthropogenic impacts on various aquatic ecosystems. In the eastern Mediterranean region river algal diversity research is not very developed, whereas algal monitoring studies of aquatic systems on European coasts [1,2] have advanced rather well. In Israel, our knowledge of regional algal diversity is far from exhaustive, and algal communities of the rivers were not regularly studied till 2000 [3].

For many years, we have collected data on algal diversity for the Upper Jordan River. The data enables us to analyze the changes in community structure from the beginning of researches at the end of the $18^{\text {th }}$ century till the present time. Moreover, we can most likely track the dynamics of species-indicators that can help us determine the time of impact and the direction of environ- mental influences on the algal communities.

Therefore, we decided to study spatial and temporal algal diversity changes in Israel's major drinking water resource - the Upper Jordan River, in respect to the fluctuation of water parameters affected by the anthropogenic impact and seasonal climate changes.

The main characteristic of Israeli climate is a short winter rainy season, which lasts from December till April. The Upper Jordan River water sources and their dynamics are similar to some of the same dynamics as those described from Southern Lebanon [4]. Algal communities as a basis for the trophic pyramid play a significant role in the water-quality forming process. Periphytonic communities show a strong potential for the recovery of ecosystems in the Mediterranean region [5-9]. Recently, we compared seasonal influences on Yarqon River communities in Israel [10]. Under similar climatic conditions and floristic realms, diatom algal communities were studied according to the same seasonal environmental 
factors as in the rivers of Egypt [11], Lebanon [12], and Turkey $[13,14]$. All of these mentioned rivers as well as the Upper Jordan River do not have a strong anthropogenic impact. Possible methods used to reveal the many influences of species indicators are: community structure fluctuation analysis, bio-indication of major influencing factors, calculations of integral density-diversity indices, and statistical approaches, which can be combined with community structure and environmental analyses as well.

\section{Materials and Methods}

\subsection{Study Area Description}

The Jordan River (320 km long) originates in the mountains of eastern Lebanon. As the Jordan River flows south through the entrance to the Great Syrian Rift Valley, it is fed from underground sources and small streams at various points in Jordan, Israel, Syria, and Lebanon [15]. Its tributaries are the Snir (Hasbani), which flows from Lebanon, Hermon (Banias), arising from a spring at Banias at the base of Mount Hermon, and the Dan and Saar, whose source is also at the base of Mount Hermon. They merge to form the Jordan River in northern Israel, near Kibbutz Sede Nehemya. The Jordan River used to drop rapidly in a 75-kilometer run into the swampy Lake Hula, which was slightly below sea level in the Rift Valley. Exiting the lake, it dropped much more, about 25 kilometers to Lake Kinneret. The last section has a lower gradient, and the river begins to meander before it enters the Dead Sea, which is about 400 meters below sea level and has no outlet. Two major tributaries enter from the East during this last phase: the Yarmouk River and Jabbok River.

The Jordan River is not only the largest and longest river that flows into Israel, but it is also the river that has a permanent flow year-round. The other major rivers in Israel are contaminated with agricultural and industrial sewage, which makes the Jordan River the only natural and clean river in the country.

It is important to emphasize that the Jordan River, in spite of its relatively large size in Israel, is actually a small river in international terms.

Data on the diversity of algal species in the Upper Jordan River Basin (including rivers, streams, lakes, wells, fishponds, and temporary water bodies) have been collected since 1883 [3,16-36] and contain 337 species and infraspecies. According to historical analyses (based on data collected from 1883-2009), we selected 227 species of algae and cyanobacteria that were found before our research in the Upper Jordan River and their tributaries from which we collected samples in 2006-2009. Our current research included analyses of the community structure dynamic and bio-indication.

\subsection{Methods}

Our research is based on 101 samples of planktonic and periphytonic algae that were collected at 21 sampling stations in the Upper Jordan River area. Samples were collected in March and May of 2006, April and August of 2007, July and April of 2008, and January, March, and April of 2009.

In 2006-2008, stations were selected in adjustment to water-quality monitoring stations used by "Mekorot" (Israel National Water Co.), most of which were located at the merging points of streams or at their outlets as follows: (1) Banias upstream; (2) Banias stream outlet; (3) Dan upstream; (4) Dan stream outlet; (5) Snir stream outlet; (6) Jordan River beginning at streams' merger; (7) Ayun stream outlet; (8) Agmon pond; (9) Under Yosef bridge; (10) Jordan River outlet to Lake Kinneret; (11) Meshushim stream outlet; (12) Yeudiyya stream outlet, and (13) Daliyyot stream outlet.

Based upon research results obtained in 2006-2007, it became apparent that more research needed to be done on the chemical properties of the water flowing into the Upper Jordan River.

In order to reveal the influence of the upper part of the basin and to understand which parts of it are most critical, the basin's structure was studied in detail. The basin's structure was studied in the rainy winter period, since at that time water-flow increases from both rainfall and melting snow; the data collected in 2006-2007 made it clear that the winter period was more critical. The structural study of the Upper Jordan River Basin in winter 2009 led to the creation of a more precise map (Figure 1).

Stations added in 2009 were: (14) upper Ayun stream; (16) upper Saar stream; (17) Saar stream below station 16; (18) upper Meshushim stream pool; (20) Saar stream below Masade; (21) Saar stream above the confluence point with the Banias stream; (22) Saar stream near the confluence with the Banias stream; (23) Birkat Ram Lake, and $(36,37)$ two stations on the small wells placed near station 2.

Samples were obtained by scooping up phytoplankton and by scratching for periphyton, and then fixed in 3\% formaldehyde. Part of the macrophyte algae was stored in the herbarium of the Institute of Evolution, University of Haifa. The algae were studied with a dissecting Swift microscope under magnifications of $740 \mathrm{x}-1850 \mathrm{x}$ and were photographed with the digital camera Inspector 1.

The diatoms were prepared with a peroxide technique [37] modified for glass slides [38]. In parallel with sampling for algae, the temperature, conductivity, TDS, and pH with the HANNA HI $9813 \mathrm{pH} / \mathrm{EC} / \mathrm{TDS}$ Meter were measured. In addition to the sampling, data obtained from the chemical analyses regularly performed by the "Mekorot Water" company were used.

Taxonomy of our research along with the data list published for the last century was adopted under a modern 


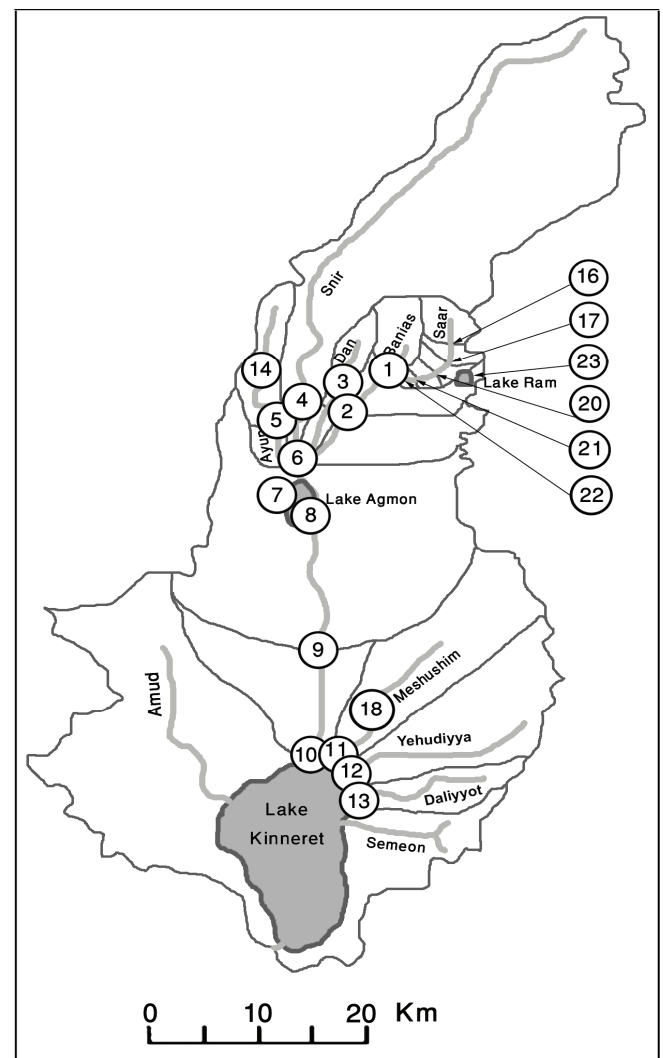

Figure 1. Basins and sampling stations' map of the Upper Jordan River in 2006-2009.

classification system [39]. The ecological data analysis of algal species diversity that was performed revealed the grouping of freshwater algae in respect to variables that were taken from the database compiled for freshwater algae in Israel [40]. Each group was separately assessed in respect to its bio-indication significance.

\section{Results and Discussion}

\subsection{Chemical Analysis Data}

Our results of chemical analysis data from field trips in 2006-2009 are shown in Tables 1, 2 [41] and 3.

Figure 2 is based on full screening data (Table 3) and displays changes in the major chemical parameters during the winter of 2009. The additional sampling stations were positioned from the headspring of the Saar stream under Mount Hermon peak (Figure 1, st. 16) all the way to the previously investigated stations on the Upper Jordan River (Figure 1, st. 2, 6, 9 and 10). Together, these stations comprise a longer water-flow path from the mountains into Lake Kinneret. Water temperature rises upon its approach to Lake Kinneret. The $\mathrm{pH}$ remains practically the same throughout the flow. Electrical conductivity and TDS both change similarly and generally increase upon their approach to the lake, yet have sig-
Table 1. Chemical analysis data, saprobity index (S), and number of species collected in December 2006.

\begin{tabular}{lcccc}
\hline No. of Station & 1 & 6 & 10 & 11 \\
\hline N Kjeldahl, mg/l & 0.10 & 0.13 & 0.27 & 0.26 \\
T, C & 15.40 & 14.80 & 14.00 & 14.00 \\
Electrical Conductivity, & 494.5 & 401.0 & 455.0 & 451.0 \\
$\mathrm{msm} / \mathrm{cm}$ & 0.10 & 0.11 & 0.25 & 0.25 \\
$\mathrm{~N}$ org., mgN/1 & 0.01 & 0.02 & 0.02 & 0.01 \\
$\mathrm{NH}_{3}, \mathrm{mg} \mathrm{N} / 1$ & 1.32 & 1.89 & 1.88 & 2.25 \\
$\mathrm{NO}_{3}, \mathrm{mgN} / 1$ & 1.43 & 1.60 & 2.10 & 2.53 \\
$\mathrm{~N} \mathrm{tot.,} \mathrm{mgN/1}_{\mathrm{pH}}$ & 7.95 & 7.90 & 7.27 & 7.84 \\
$\mathrm{PO}_{4}, \mathrm{mgP} / 1$ & 0.06 & 0.02 & 0.05 & 0.0295 \\
$\mathrm{P}$ tot., mgP/1 & 0.07 & 0.04 & 0.12 & 0.041 \\
$\mathrm{Cl}, \mathrm{mg} / 1$ & 13.0 & 10.0 & 13.0 & 29.0 \\
Index of Saprobity (S) & 1.47 & 1.74 & 1.60 & $1.73-1.87$ \\
No. of Species & 8.00 & 42.00 & 28.00 & $24-25$ \\
\hline
\end{tabular}

Table 2. Chemical substance analysis data, saprobity index, and number of species collected in March 2006.

\begin{tabular}{|c|c|c|c|c|c|c|c|c|}
\hline $\begin{array}{l}\text { No. of } \\
\text { Station }\end{array}$ & 1 & 2 & 4 & 5 & 6 & 9 & 10 & 11 \\
\hline $\mathrm{T}, \mathrm{C}^{\circ}$ & 17 & 18 & 20 & 20 & 18 & 19 & 21.5 & 20 \\
\hline $\begin{array}{l}\text { Elect. } \\
\text { Cond., } \\
\mathrm{msm} / \mathrm{cm}\end{array}$ & 349 & 389 & 336 & 391 & 371 & 413 & 406 & 452 \\
\hline $\mathrm{N}$ org., mg & 0.11 & 0.10 & 0.01 & 0.09 & 0.08 & 0.15 & 0.20 & 0.08 \\
\hline $\begin{array}{l}\mathrm{NH}_{3}, \mathrm{mg} \\
\mathrm{N} / 1 \\
\mathrm{NO}_{3}, \mathrm{mg}\end{array}$ & 0.01 & 0.02 & 0.02 & 0.05 & 0.03 & 0.04 & 0.02 & 0.03 \\
\hline $\begin{array}{l}\mathrm{N} / 1 \\
\mathrm{~N} \text { tot., mg }\end{array}$ & 1.04 & 1.27 & 1.08 & 1.55 & 1.29 & 1.61 & 1.54 & 1.96 \\
\hline $\mathrm{N} / 1$ & 1.09 & 1.34 & 1.45 & 1.71 & 1.38 & 1.79 & 1.62 & 2.03 \\
\hline $\mathrm{pH}$ & 7.44 & 8.07 & 7.81 & 8.12 & 8.29 & 8.13 & 8.3 & 8.38 \\
\hline $\begin{array}{l}\mathrm{PO}_{4}, \\
\text { mg P/1 } \\
\text { P tot., mg }\end{array}$ & 0.02 & 0.02 & 0.01 & 0.01 & 0.02 & 0.02 & 0.03 & 0.05 \\
\hline $\begin{array}{l}\mathrm{P} / 1 \\
\text { Index }\end{array}$ & 0.03 & 0.04 & 0.01 & 0.03 & 0.03 & 0.04 & 0.07 & 0.06 \\
\hline $\begin{array}{l}\text { Saprobity } \\
\text { (S) }\end{array}$ & 1.60 & 0.70 & 2.00 & 1.40 & 1.30 & 1.30 & 1.30 & 1.94 \\
\hline $\begin{array}{l}\text { No. of } \\
\text { Species }\end{array}$ & 9 & 8 & 13 & 11 & 17 & 20 & 15 & 17 \\
\hline
\end{tabular}

nificant peaks at on stations 17 and 2. Station 17 is situated downstream from agricultural enterprises at the foot of Mount Hermon.

Station 2 is located after the confluence of the Banias stream. Stations 16-22 are of a mountainous-piedmont nature of effluence, whereas stations 2-10 are more planar. This difference in the effluence types might be the cause for the overall change in the quantity of ions (TDS, Conductivity) and phosphates, as illustrated in Figure 2.

The high chloride concentration could be a result of effluence from Masade before station 20. However, during the highly polluted winter period, the self-purification process in the river is also the highest as nitrate levels drop. 
Table 3. Chemical substance analysis data, saprobity index, and number of species collected in February-April 2009.

\begin{tabular}{|c|c|c|c|c|c|c|c|c|c|c|c|c|c|c|c|c|c|c|c|c|c|}
\hline Station no & 1 & 2 & 3 & 4 & 5 & 6 & 9 & 10 & 11 & 12 & 13 & 14 & 16 & 17 & 18 & 20 & 21 & 22 & 23 & 36 & 37 \\
\hline $\begin{array}{l}\text { N Kjeldahl, } \\
\mathrm{mg} / \mathrm{l}\end{array}$ & 1.7 & 1.7 & 1.7 & 1.7 & 2.3 & 1.1 & 0.5 & 2.4 & 0.2 & 0.2 & 1.4 & 1.1 & 1.7 & 1.7 & 0.5 & 1.9 & 2.4 & 2.3 & 3 & 1.7 & 1.7 \\
\hline $\mathrm{T}$ & 14.8 & 15.3 & 14.8 & 14.2 & 17.5 & 14.4 & 17.4 & 15 & 16.1 & 16.4 & 16.5 & 11.8 & 14.6 & 11.4 & 20.2 & 15.5 & 15.3 & 12.4 & 10.9 & 15.0 & 13.1 \\
\hline $\begin{array}{l}\text { Electrical } \\
\text { Conductivity } \\
\end{array}$ & 0.42 & 0.42 & 0.31 & 0.34 & 0.41 & 0.34 & 0.35 & 0.61 & 0.4 & 0.44 & 0.53 & 0.54 & 0.30 & 0.42 & 0.37 & 0.31 & 0.3 & 0.34 & 0.28 & 0.52 & 0.26 \\
\hline TDS & 294 & 297 & 217 & 244 & 287 & 240 & 248 & 431 & 281 & 310 & 374 & 378 & 216 & 185 & 264 & 215 & 215 & 209 & 162 & 366 & 188 \\
\hline $\mathrm{N}$ org., $\mathrm{mg} / 1$ & 1.7 & 1.7 & 1.7 & 1.7 & 2.3 & 1.1 & 0.5 & 2.4 & 0.2 & 0.2 & 1.4 & 1.1 & 1.7 & 1.7 & 0.5 & 1.9 & 2.4 & 2.3 & 3 & 1.7 & 1.7 \\
\hline $\mathrm{NH} 3, \mathrm{mg} / \mathrm{l}$ & 0 & 0 & 0 & 0 & 0 & 0 & 0 & 0 & 0 & 0 & 0 & 0 & 0 & 0 & 0 & 0 & 0 & 0 & 0 & 0 & 0 \\
\hline $\mathrm{N}-\mathrm{NO} 3, \mathrm{mg} / 1$ & 2.3 & 2.9 & 1.8 & 2.2 & 2.1 & 1.9 & 2.5 & 1.3 & 1.7 & 1.7 & 1.2 & 1.7 & 4.0 & 4.2 & 2.7 & 3.7 & 3.8 & 2.3 & 0.8 & 6.5 & 1.8 \\
\hline $\mathrm{N}$ tot., $\mathrm{mg} / \mathrm{l}$ & 4 & 4.6 & 3.5 & 3.9 & 4.4 & 3 & 3 & 3.7 & 1.9 & 1.9 & 2.6 & 2.8 & 5.7 & 5.9 & 3.2 & 5.6 & 6.2 & 4.6 & 3.8 & 8.2 & 3.5 \\
\hline $\mathrm{pH}$ & 7.5 & 8.3 & 8.3 & 8.3 & 8.4 & 8.3 & 8.2 & 8.4 & 8.4 & 8.3 & 8.5 & 8.0 & 8.1 & 8.5 & 8.3 & 8.8 & 8.9 & 8.1 & 8.7 & 7.9 & 8.2 \\
\hline PO4, mg/1 & 0 & 0 & 0 & 0 & 0 & 0 & 0 & 0 & 0 & 0 & 0 & 0 & 0 & 0 & 0 & 0 & 0 & 0 & 0 & 0 & 0 \\
\hline P tot., $\mathrm{mg} / 1$ & 0.1 & 0 & 0 & 0 & 0 & 0 & 0 & 0 & 0 & 0 & 0 & 0 & 0.1 & 0.2 & 0 & 0.1 & 0.1 & 0.1 & 0.3 & 0 & 0.1 \\
\hline $\mathrm{Cl}, \mathrm{mg} / \mathrm{l}$ & 16.0 & 15.0 & 11.0 & 14.0 & 25.0 & 13.0 & 35.9 & 25.2 & 27 & 55 & 50.8 & 41.0 & 19.0 & 29.0 & 31.2 & 38 & 37 & 37.0 & 22.0 & 20.0 & 10.7 \\
\hline $\begin{array}{l}\text { Index of } \\
\text { Saprobity (S) }\end{array}$ & 1.03 & 1.56 & 0.93 & 1.45 & 1.39 & 1.71 & 1.56 & 1.32 & 1.28 & 1.27 & 1.15 & 1.17 & 1.00 & 1.54 & 1.31 & 1.12 & 1.48 & 1.65 & 1.75 & 1.28 & 1.39 \\
\hline
\end{tabular}

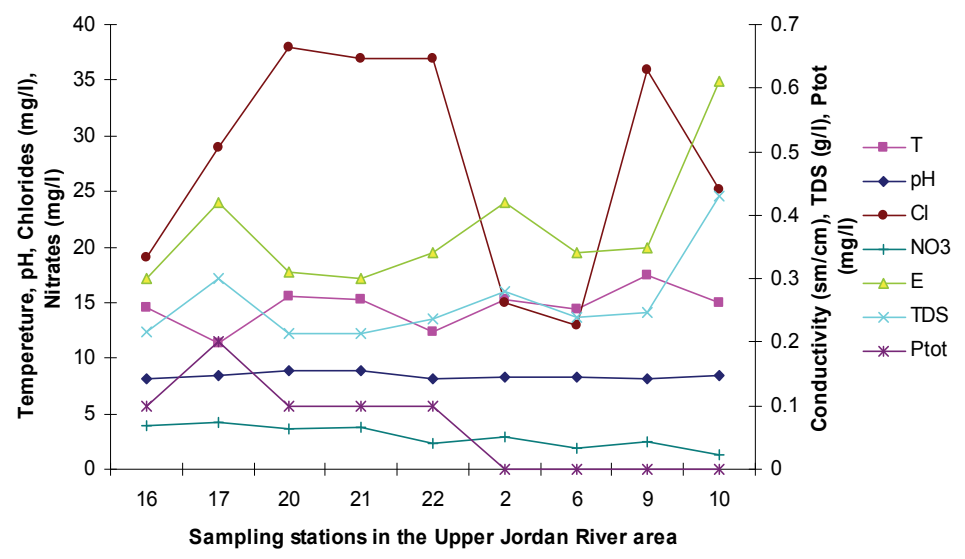

Figure 2. Chemical and physical parameters as measured in winter of 2009 at monitoring stations in the Upper Jordan River Basin.

Since the chemical monitoring by the Mekorot Company is performed only in sampling stations $1,2,6$, and 10 , samples had to be collected for a chemical analysis, parallel to the algological samples in other older and newer sampling stations.

\subsection{The Last Century Dynamic of the Taxonomic Structure and Bioindicators in the Upper Jordan River Area, Historical Overview (1883-2009)}

The following analysis includes our data collected in 2006-2009 as well as data from known international literature regarding species diversity in the Upper Jordan River [3,16-36]. Before our research in the Upper Jordan River area (including the river itself, tributaries, temporary streams, pools, fishponds, temporary water bodies, and lakes), there were 337 species and infraspecies of algae and cyanobacteria found. Therefore, the full species list now contains 467 taxa together with our findings of 232 taxa (for a total of 466 taxa, which includes our finding of 232 taxa) in 2006-2009. For our historical analysis, we selected taxa that were found during 1883-
2000 only in the river and in their tributaries where we studied diversity, including 227 species and infraspecies. The diagram of the species diversity dynamics cover more than the past 100 years (Figure 3) and included our 2006-2009 findings.

As can be seen (Figure 3), species richness of the algal communities in the Upper Jordan River that was presented in mentioned references by 227 species and infraspecies fluctuated during the last century with peaks in $1951,1965,1978$, and the present time. We significantly enriched the species list from 2006-2009 that was represented by 232 taxa of algae and cyanobacteria (Table 4) from which 85 taxa were new for the Upper Jordan River Basin, and three of them were mentioned for the first time in Israel. The revealed diversity belonged to seven taxonomic divisions. Bacillariophyta (Diatoms) were dominant but in order to clarify the change in algal communities' structure we constructed a percentage diagram (Figure 4), which shows some major periods when aquatic communities were impacted.

The first period showed a rather large increase in the number of species, which occurred in the middle of the last century. This was probably a result of mild organic 


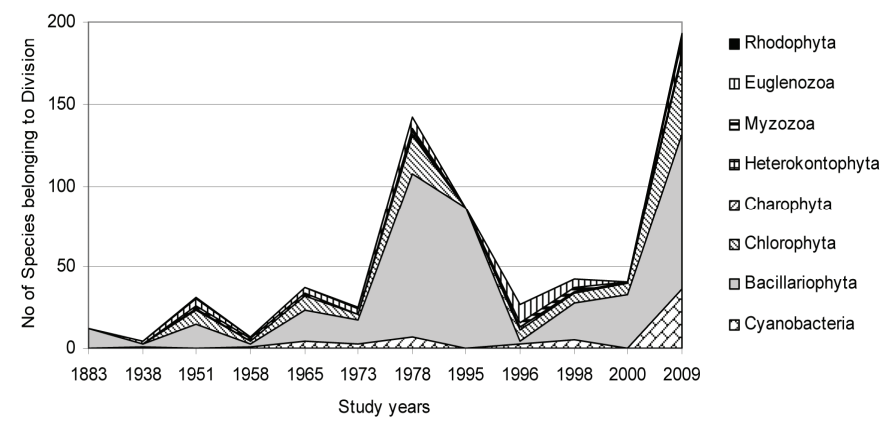

Figure 3. Species diversity dynamics in algal communities of the Upper Jordan River during the last century.

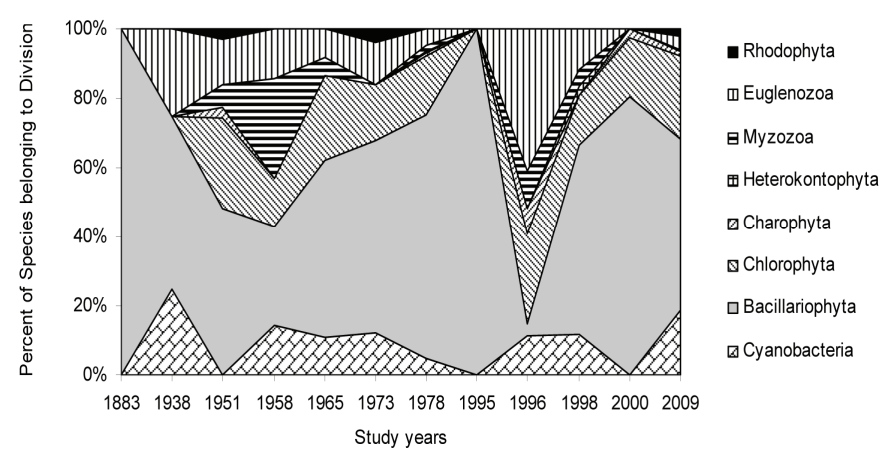

Figure 4. Historical overview (1883-2009) of the algal communities' structural changes in the Upper Jordan River.

pollution introduced primarily to this environment from 1951 and ended in 1965, as a result of the drying up the Hula Lake and the prevailing agriculture that replaced it [49]. Another climax in the number of species occurred during the period of 1973-1996; it seemed to reach its peak in 1978, but then in 1996 a dramatic decrease in the number of species occurred (about an 80\% decrease), and instead, new species, previously unknown to this area, appeared in relatively high numbers. These newly emerged species are known indicators of organically polluted water with high temperatures and high salinity. With time, as the pollution decreased, the system started to return to its previous state (the state prior to pollution); by 2009 , species common to the divisions typical to this area returned.

Figures 5-10 reveal the results of bioindication of major environmental parameters' fluctuation during the last century. As can be seen by species indicators from the figures, the algal community of the Upper Jordan River was stressed by temperature at a time when the taxonomic structure was changed in the middle of the last century and in 1996 (Figure 5). Water salinity stress was indicated in 1938 and 2000 (Figure 6). An impact of acidification was indicated in 1938, 1996, and 2000 (Figure 7). A dramatic decrease in the high-quality classes' indicators reflected an organic pollution impact in 1996 (Figure 8). The nitrogen uptake metabolism (photosynthetic) type indicators [48] changed in 1938 and 1996 with dominating facultatively nitrogen-heterotrophic taxa that needed periodically elevated concentra- tions of organically bound nitrogen (Figure 9). Their presence usually correlates with an impact of pollution.

The eutraphentic species indicators constituted the whole community in 1958 and 1996, whereas for 1995 and 2000 Figure 10 shows two peaks of eutrophication marked by invasive high-trophic level indicators - hypereutraphentics [48].

It is interesting to note that the eutrophication trend can be seen from the 1970s till now, as indicated by the increase in eutraphentic and hypereutraphentic species.

\subsection{Taxonomic Structure and Self-Purification Dynamic in the Upper Jordan River throughout the Sampling Stations in Winter 2009}

As seen in Figure 11, the community of the Upper Jordan River Channel is comprised today mostly of Bacillariophyta (diatoms). There are three peaks in the fluctuation of diversity. The first peak is located at the Saar tributary above the Masade village (Stations 16-17), a community of 33-34 species. In addition to the diatoms, there are green algae and euglenoids, a result of the presence of organic pollution. At stations 20 and 21, after the Masade effluence, as a result of an anthropogenic influence, there is a sharp decrease in the number of species - to about 17-20 and an impoverishment of algal complexes. Afterwards, at stations 21 and 22, the com- 


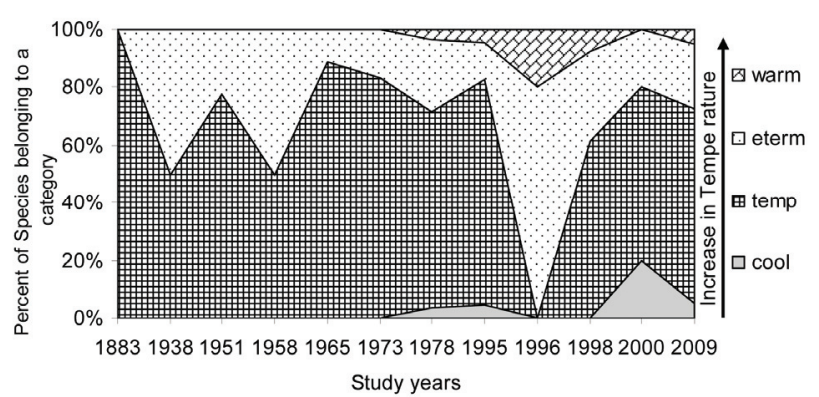

Figure 5. Historical overview (1883-2009) of the temperature indicator changes in the Upper Jordan River. Legend: warm warm water, eterm - eurythermic, temp - temperate, cool - cool water.

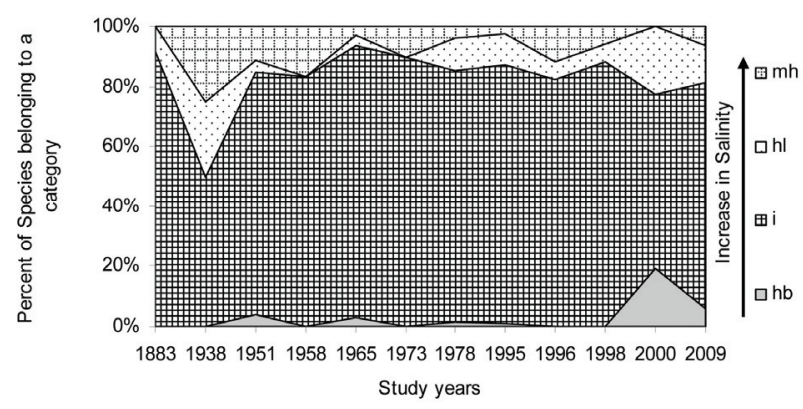

Figure 6. Historical overview (1883-2009) of the salinity indicator changes in the Upper Jordan River. Legend: halobity degree on Hustedt's scale [43] (hb - oligohalobes-halophobes, $\mathrm{i}$ - oligohalobes-indifferents, $\mathrm{mh}$ - mesohalobes, hl - halophiles).

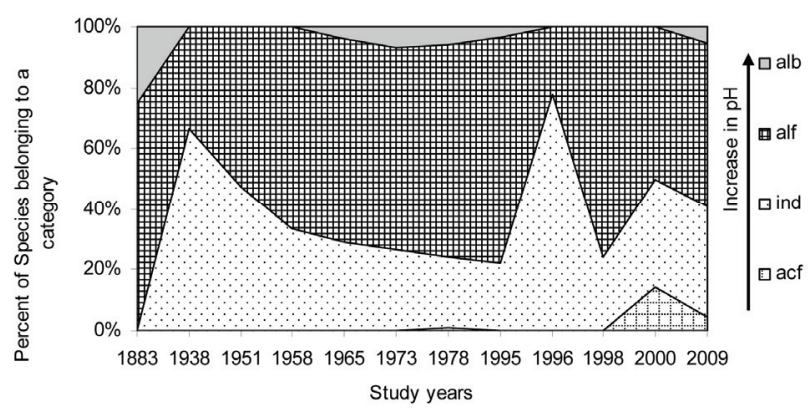

Figure 7. Historical overview (1883-2009) of the acidity (pH) indicator changes in the Upper Jordan River. Legend: pH degree on Hustedt's scale [44] (alb-alkalibiontes; alf - alkaliphiles, ind - indifferents; acf - acidophiles; neu - neutrophiles, which were mentioned in Table 4 affiliated with indifferents but have a narrower ecological specter).



Figure 8. Historical overview (1883-2009) of the organic pollution indicator [45,46] changes in the Upper Jordan River. Legend: 1 Class - saprobity index is 0.0-0.5; 2 Class - saprobity index is $0.5-1.5 ; 3$ Class - saprobity index is $1.5-2.5$; 4 Class saprobity index is $2.5-3.5$; 5 Class - saprobity index is 3.5-4.0. 




Figure 9. Historical overview (1883-2009) of the nitrogen uptake metabolism (photosynthetic) type indicator changes in the Upper Jordan River. Legend: Nitrogen uptake metabolism [48] (ats - nitrogen-autotrophic taxa, tolerating very small concentrations of organically bound nitrogen; ate - nitrogen-autotrophic taxa, tolerating elevated concentrations of organically bound nitrogen; hne - facultatively nitrogen-heterotrophic taxa, needing periodically elevated concentrations of organically bound nitrogen; hce - obligately nitrogen-heterotrophic taxa, needing continuously elevated concentrations of organically bound nitrogen).

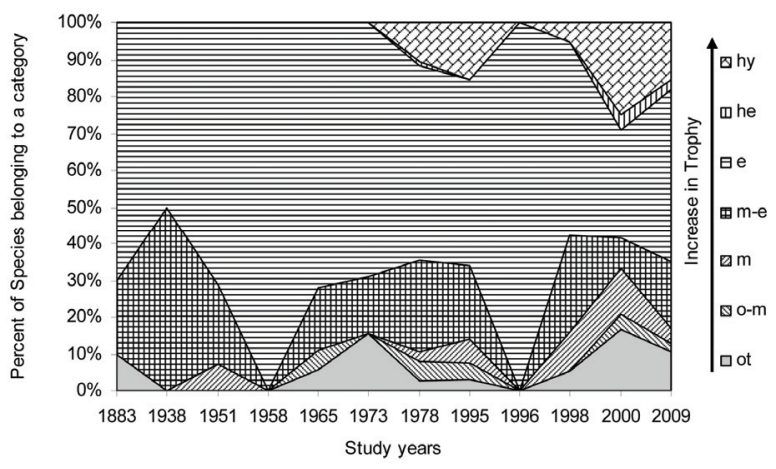

Figure 10. Historical overview (1883-2009) of the trophic status indicator changes in the Upper Jordan River. Legend: Trophic state [48] (ot - oligotraphentic; o-m - oligo-mesotraphentic; $\mathbf{m}$ - mesotraphentic; m-e - meso-eutraphentic; e - eutraphentic; he - hypereutraphentic; hy - oligo- to eutraphentic (hypereutraphentic)).



Figure 11. Algal species taxonomic structure changes in the sampling stations of the Upper Jordan River from upper reaches of the longest Saar tributary till the river mouth (winter 2009).

munities restored the diversity by means of self-purification and the addition of green algae and euglenoids. At the point of confluence with the clean waters of the Banias River (Station 2), the communities' composition reaches maximal diversity with 45 species. At this point, the red algae finally appear. At station 6, after the con- fluence with the three right-side tributaries (Figure 1), a drop in diversity occurs, however, it is again restored at station 9, where once again red algae enter the complex as indicators of self-purification. At the lower flow, near the entrance into Lake Kinneret, the community composition is less complex and includes diatoms, euglenoids, 
and cyanobacteria. Diversity is lowered to just 16 species accompanied by an impoverishment of the complex and the presence of euglenoids, which once more reflects the presence of anthropogenic factors affecting the algal community.

The fluctuations in diversity and the algal communities' composition at the basin confirm that, periodically, the presence of anthropogenic influences alters the formation of algal communities. However, these fluctuations are also related to the activity level of the self-purification process in the river. As can be seen in Figure 12, the fluctuation in species richness correlates with the saprobity index S value over the sampling stations in winter 2009. It can reflect the initial stage of the self-purification process, while the nutrient-enriched water gives a basis for diversity development in the community. This type of correlation can be related also with the oligotrophic status of the Upper Jordan River because the initial stage of eutrophication offers the best start for community development.

\subsection{Taxonomic Composition Analysis in the Upper Jordan River Basin}

Upon evidence of the species richness dynamic and its relationship with the trophic status of this river, we can see a highly significant role in algal diversity in the analysis of the river state. Species diversity in communities of each tributary reflects the state of their environments. Therefore, we can use the algal community composition structure in tributaries as an instrument for the clustering of species diversity of the Upper Jordan Basin as a whole. For this analysis, we divided all revealed species diversity for the studied period (2006-2009) into 11 species lists (Table 4) for each tributary, the river itself, and the two lakes, Hula and Ram (a volcanic crater lake between Majdel Shams and Masade). The taxonomic structure of each object was analyzed on the infraspecies level by the clustering methods in the "GRAPHS" program [50].

Clustering by the Serensen-Chekanovsky indices divided algal diversity into five different groups based on the similarity level, which was 40\% (Figure 13). One cluster included the Mount Hermon piedmont streams: Saar, Banias, and Dan. The Upper Jordan (lower reaches) and Meshushim, flowing into Lake Kinneret close to each other, constitute the second cluster. More planer tributaries, such as the Daliyyot, Yehudiyya, Snir, and Ayun, located in the northern part of the river basin, formed the third cluster. Two different clusters included the two lakes, Hula and Ram volcanic crater lake with differences in hydrology from all of the rivers' tributaries. Therefore, river diversity was divided into five clusters, according to their hydrology.

The tree of taxonomic diversity clusters was constructed on the basis of revealed species diversity of the Upper Jordan River; the tributaries and lakes show (Figure 14) four different branches. As can be seen, the most similar (53\%) diversity belonged to the Snir and Ayun rivers, located close to the northwest part of the river basin. This group also included the Yehudiyya River with similar hydrology. The second branch is formed by the mouth of the Upper Jordan River and the Meshushim River (49\% similarity), both flowing into Lake Kinneret close to each other. The Saar, Banias, and Dan rivers were in the third group comprising $45 \%$ similarity. This group was located close to the northeastern part of the basin and has similar hydrology. The last group included the two lakes, Ram and Hula, as well as the Daliyyot River. The sampling station on this river was located in the lower pond of the river. Therefore, the hydrology of each river influenced species diversity significantly, and diversity can be used as a marker of hydrologically similar tributaries of the basin.

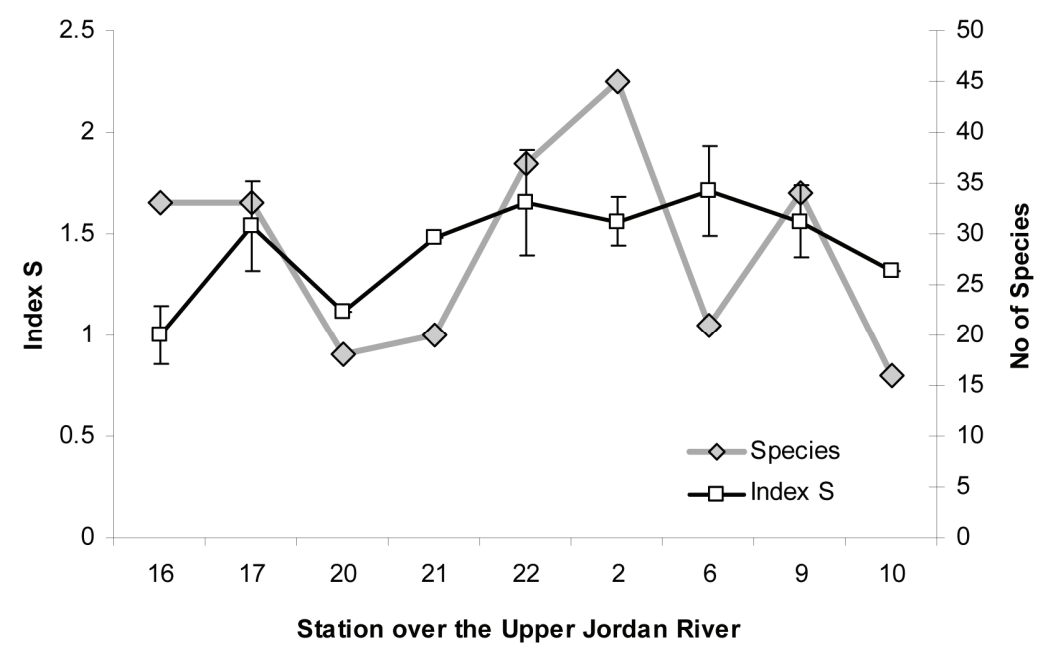

Figure 12. Algal species richness in communities and saprobity index $S$ changes in the sampling stations of the Upper Jordan River in winter 2009. 


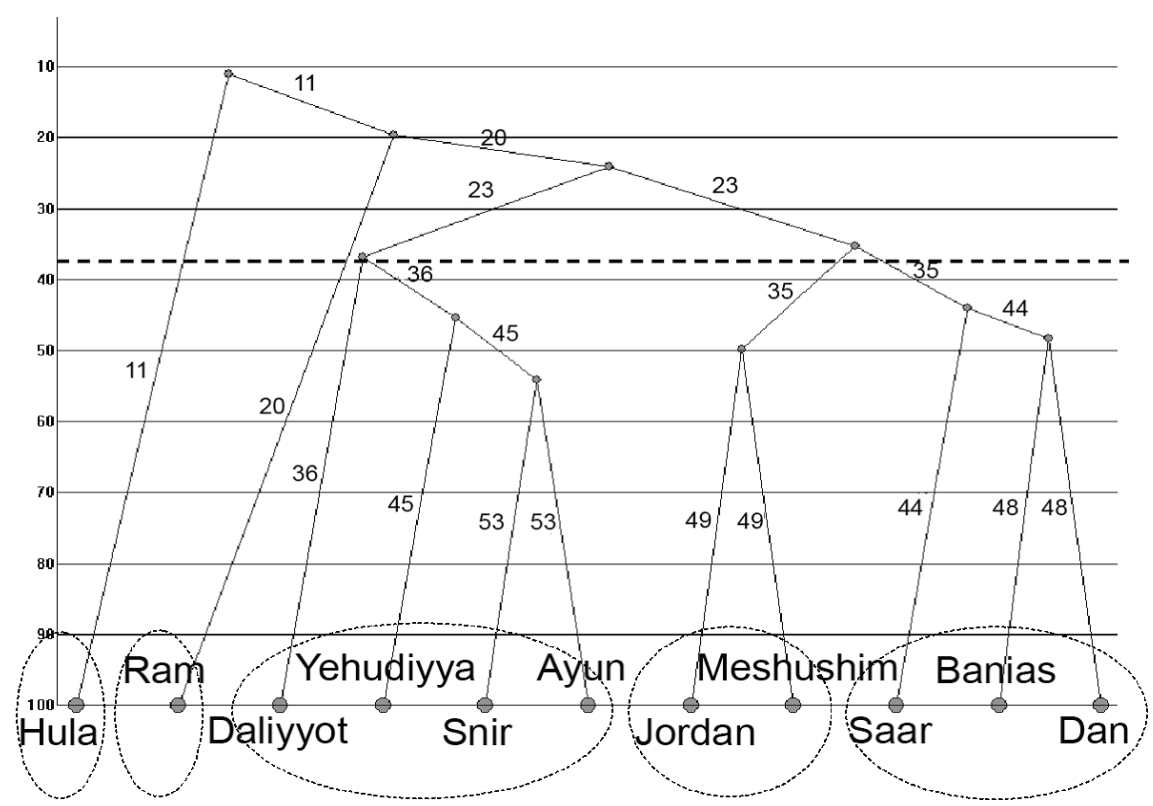

Figure 13. Clustering of the taxonomic structure in the rivers of the Upper Jordan River basin on the basis of SerensenChekanovsky indices.

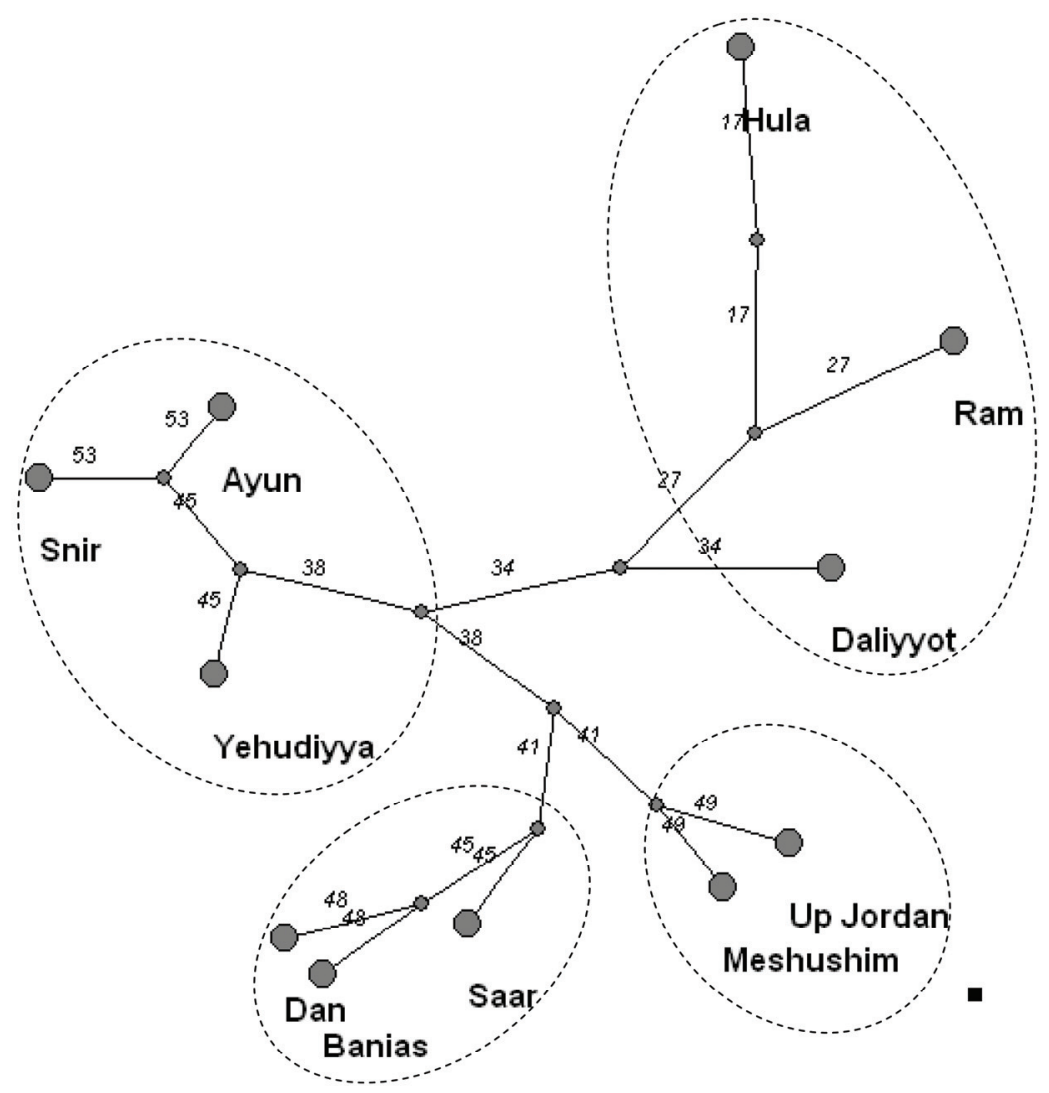

Figure 14. Tree of the taxonomic structure in the rivers of the Upper Jordan River basin on the basis of Serensen-Chekanovsky indices and brave calculation. The group of Banias, Dan, and Saar included cool piedmount streams; the group of Snir, Ayun, and Yehudiyya included piedmount streams that partly flow into the river plane; the group of Upper Jordan and Meshushim included plane streams; the group of Hula and Ram (lakes), and Daliyyot had ponded objects. 
Table 4. Diversity and ecology of species in the Upper Jordan River communities in 2006-2009.

\begin{tabular}{|c|c|c|c|c|c|c|c|c|c|c|c|c|c|c|c|c|c|}
\hline Taxon & Banias & Dan & Snir & Ayun & $\begin{array}{l}\text { Jor- } \\
\text { dan }\end{array}$ & $\begin{array}{l}\text { Yehu- } \\
\text { diyya }\end{array}$ & $\begin{array}{c}\text { Meshu- } \\
\text { shim }\end{array}$ & $\begin{array}{c}\text { Daliy- } \\
\text { yot }\end{array}$ & Saar & Ram & Hula & $\mathrm{S}$ & $\mathrm{pH}$ & Hal & Sap & Het & Tro \\
\hline \multicolumn{18}{|l|}{ Cyanobacteria } \\
\hline $\begin{array}{l}\text { Anabaena pseudoscillatoria } \\
\text { Bory de Saint-Vincent }\end{array}$ & - & 1 & 3 & 1 & - & - & - & - & - & - & - & 2.0 & - & - & $\mathrm{b}$ & - & - \\
\hline Anabaena sp. & - & 1 & - & - & - & - & - & - & - & - & - & - & - & - & - & - & - \\
\hline *Anabaena spiroides Klebahn & - & - & - & - & - & - & - & - & - & - & 1 & 1.5 & - & $\mathrm{i}$ & o-b & - & - \\
\hline $\begin{array}{l}\text { Aphanothece clathrata W. } \\
\text { West \& G.S. West }\end{array}$ & - & - & - & - & 2 & - & - & - & - & - & - & 2.3 & - & hl & $\mathrm{b}$ & - & - \\
\hline Calothrix sp. & - & - & - & - & 2 & - & 1 & 1 & - & - & - & & - & - & - & - & - \\
\hline $\begin{array}{l}\text { Chamaesiphon incrustans } \\
\text { Grunow }\end{array}$ & 1 & 4 & - & - & - & - & 2 & - & - & - & - & 1.0 & - & - & $\mathrm{o}$ & - & - \\
\hline Chamaesiphon sp. & - & - & - & 2 & - & - & - & - & - & - & - & - & - & - & - & - & - \\
\hline $\begin{array}{l}\text { Chlorogloea microcystoides } \\
\text { Geitler }\end{array}$ & 2 & - & - & - & - & - & - & - & - & - & - & - & - & - & - & - & - \\
\hline Chroococcidiopsis sp. & - & - & - & - & - & - & 5 & - & - & - & - & - & - & - & - & - & - \\
\hline Chroococcus sp. & - & 2 & - & - & - & - & 3 & - & - & - & - & - & - & - & - & - & - \\
\hline $\begin{array}{l}\text { *Chroococcus turgidus } \\
\text { (Kützing) Nägeli }\end{array}$ & 2 & 2 & - & 1 & - & - & 1 & - & - & - & - & 1.3 & alf & hl & $\mathrm{o}$ & - & - \\
\hline $\begin{array}{l}\text { Coelosphaerium } \\
\text { kuetzingianum Nägeli }\end{array}$ & - & - & - & - & 1 & - & - & - & - & - & - & 1.6 & - & $\mathrm{i}$ & b-o & - & - \\
\hline Coelosphaerium sp. & - & - & - & - & 4 & - & - & - & - & - & - & - & - & - & - & - & - \\
\hline $\begin{array}{l}* * \text { Cyanostylon } \\
\text { microcystoides Geitler }\end{array}$ & - & - & - & - & - & - & 6 & - & - & - & - & - & - & - & - & - & - \\
\hline $\begin{array}{l}\text { Gloeocapsopsis crepidinum } \\
\text { (Thuret) Geitler ex Komàrek }\end{array}$ & - & $2-3$ & 1 & $1-2$ & - & - & 1 & - & - & - & - & - & - & hl & - & - & - \\
\hline $\begin{array}{l}\text { *Heteroleibleinia } \\
\text { kossinskajae(Elenkin) } \\
\text { Anagnostidis \& Komárek }\end{array}$ & - & - & 6 & - & - & - & - & - & - & - & - & - & - & - & - & - & - \\
\hline $\begin{array}{l}\text { Heteroleibleinia kuetzingii } \\
\text { (Schmidle) Compère }\end{array}$ & - & 4 & 3 & - & - & - & - & - & - & - & 2 & 1.5 & - & - & o-b & - & - \\
\hline $\begin{array}{l}\text { Homoeothrix janthina } \\
\text { (Bornet \& Flahault) Starmach }\end{array}$ & - & - & - & 6 & - & 6 & $5-6$ & - & - & - & - & 0.8 & - & - & $x-b$ & - & - \\
\hline $\begin{array}{l}\text { Homoeothrix juliana } \\
\text { (Meneghini) Kirchner }\end{array}$ & - & - & 6 & - & - & - & - & - & - & - & - & - & - & - & - & - & - \\
\hline Homoeothrix sp. & - & - & 6 & - & - & - & 6 & - & - & - & - & - & - & - & - & - & - \\
\hline Homoeothrix varians Geitler & 6 & - & 4 & 6 & $1-6$ & - & $4-5$ & - & - & - & - & 1.0 & - & - & $\mathrm{o}$ & - & - \\
\hline $\begin{array}{l}\text { Komvophoron constrictum } \\
\text { (Szafer) Anagnostidis \& } \\
\text { Komárek }\end{array}$ & 1 & - & - & - & - & - & - & - & - & - & - & 4.5 & - & - & $\mathrm{i}$ & - & - \\
\hline $\begin{array}{l}\text { Leptochaete stagnalis Hans- } \\
\text { girg }\end{array}$ & - & - & - & - & 3 & - & 6 & - & - & - & - & 2.0 & - & $\mathrm{i}$ & $\mathrm{b}$ & - & - \\
\hline Lyngbya sp. & $1-2$ & $2-3$ & - & $2-3$ & $1-3$ & 1 & $1-2$ & - & - & - & - & - & - & - & - & - & - \\
\hline *Merismopedia minima Beck & - & - & - & - & - & - & 2 & - & - & - & - & - & - & - & - & - & - \\
\hline $\begin{array}{l}\text { *Merismopedia punctata } \\
\text { Meyen }\end{array}$ & - & - & - & - & - & - & - & 1 & - & - & - & 1.9 & ind & $\mathrm{i}$ & o-a & - & - \\
\hline Microcrocis sp. & 1 & - & - & - & - & - & - & - & - & - & - & - & - & - & - & - & - \\
\hline $\begin{array}{l}\text { *Microcystis aeruginosa } \\
\text { (Kützing) Kützing }\end{array}$ & - & - & - & - & $2-3$ & - & - & - & - & - & - & 1.8 & - & $\mathrm{hl}$ & o-a & - & - \\
\hline $\begin{array}{l}\text { Nostoc linckia (Roth) } \\
\text { Bornet ex Bornet \& Flahault }\end{array}$ & - & - & - & 6 & - & - & - & - & - & - & - & 1.8 & - & - & o-a & - & - \\
\hline $\begin{array}{l}\text { Oscillatoria amoena } \\
\text { (Kützing) Gomont }\end{array}$ & $2-6$ & - & - & $1-3$ & 5 & - & 1 & - & $5-6$ & - & - & 0.2 & - & - & $\mathrm{x}$ & - & - \\
\hline Oscillatoria sp. & $1-3$ & 3 & - & $3-4$ & - & - & $3-6$ & - & 2 & - & - & - & - & - & - & - & - \\
\hline $\begin{array}{l}* * \text { Phormidiochaete } \\
\text { fusca } \text { (Starmach) } \\
\text { Komarek et Anagnostidis }\end{array}$ & - & - & 2 & 4 & - & - & - & - & - & - & - & - & - & - & - & - & - \\
\hline $\begin{array}{l}\text { *Phormidium ambiguum } \\
\text { Gomont }\end{array}$ & - & 5 & - & - & 1 & - & 6 & - & $3-4$ & - & - & 2.0 & ind & $\mathrm{i}$ & $\mathrm{b}$ & - & - \\
\hline $\begin{array}{l}\text { Phormidium autumnale } \\
\text { (C. Agardh) Trevisan }\end{array}$ & - & 2 & - & 2 & $1-2$ & - & - & 3 & 1 & - & - & 2.1 & - & - & b & - & - \\
\hline
\end{tabular}


Table 4 - Continued

\begin{tabular}{|c|c|c|c|c|c|c|c|c|c|c|c|c|c|c|c|c|c|}
\hline ex Gomont & & & & & & & & & & & & & & & & & \\
\hline $\begin{array}{l}\text { Phormidium breve } \\
\text { (Kützing ex Gomont) } \\
\text { Anagnostidis et Komárek }\end{array}$ & - & $1-6$ & - & $1-2$ & $2-4$ & - & - & 1 & 6 & - & - & 2.8 & - & - & b-p & - & - \\
\hline $\begin{array}{l}\text { Phormidium limosum } \\
\text { (Dillwyn) P.C. Silva }\end{array}$ & - & - & - & - & - & - & - & 3 & - & - & - & 2.3 & - & hl & $\mathrm{b}$ & - & - \\
\hline Phormidium sp. & $1-5$ & 6 & - & - & 2 & - & - & - & 6 & - & - & - & - & - & - & - & - \\
\hline $\begin{array}{l}\text { Phormidium subfuscum } \\
\text { Kützing ex Gomont }\end{array}$ & 6 & - & - & - & - & - & - & - & - & - & - & 2.0 & - & - & $\mathrm{b}$ & - & - \\
\hline $\begin{array}{l}\text { *Phormidium uncinatum } \\
\text { (C. Agardh) Gomont ex Go- } \\
\text { mont }\end{array}$ & - & - & - & - & - & - & 1 & - & - & - & - & 2.1 & - & $\mathrm{i}$ & $\mathrm{b}$ & - & - \\
\hline $\begin{array}{l}\text { *Planktothrix agardhii } \\
\text { (Gomont) Anagnostidis } \\
\text { et Komárek }\end{array}$ & - & - & - & - & - & - & - & - & 6 & - & - & 1.6 & - & hl & b-o & - & - \\
\hline $\begin{array}{l}\text { Rivularia haematites } \\
\text { (De Candolle) Bornet } \\
\text { et Flahault }\end{array}$ & - & - & - & - & - & - & 2 & - & - & - & - & 1.9 & - & - & $\mathrm{o}-\mathrm{a}$ & - & - \\
\hline $\begin{array}{l}\text { Synechococcus elongates } \\
\text { (Nägeli) Nägeli }\end{array}$ & - & 3 & - & - & - & - & - & - & - & - & - & 0.1 & - & - & $\mathrm{x}$ & - & - \\
\hline Synechococcus sp. & - & 4 & - & - & 3 & - & - & - & - & - & - & - & - & - & - & - & - \\
\hline Euglenozoa & & & & & & & & & & & & & & & & & \\
\hline $\begin{array}{l}\text { Colacium cyclopicola } \\
\text { (Gicklh.) Bourr. }\end{array}$ & - & - & - & - & - & - & - & - & - & - & 2 & 2.7 & - & - & $a-b$ & - & - \\
\hline $\begin{array}{l}\text { *Euglena deses } \mathrm{f} . \\
\text { Klebsii (Lemmermann) } \\
\text { T.G. Popova }\end{array}$ & - & - & - & - & - & - & - & - & 1 & - & - & - & - & - & - & - & - \\
\hline $\begin{array}{l}\text { Euglena limnophila } \\
\text { Lemmermann }\end{array}$ & - & - & - & - & 1 & - & - & - & - & 1 & - & 1.5 & - & - & o-b & - & - \\
\hline Euglena sp. & - & - & - & - & - & - & - & - & 1 & - & - & - & - & - & & - & - \\
\hline $\begin{array}{l}\text { Euglena spathirhyncha } \\
\text { H.L. Skuja }\end{array}$ & - & - & - & - & - & - & - & - & 1 & - & - & 3.5 & - & $\mathrm{i}$ & $a-p$ & - & - \\
\hline $\begin{array}{l}\text { *Euglena tripteris } \\
\text { (Dujardin) Klebs }\end{array}$ & - & - & - & - & 1 & - & - & - & - & - & - & 2.1 & ind & $\mathrm{mh}$ & $\mathrm{b}$ & - & - \\
\hline $\begin{array}{l}\text { Lepocinclis ovum } \\
\text { (Ehrenberg) Lemermann }\end{array}$ & - & 1 & - & - & - & - & - & - & - & 1 & - & 2.7 & ind & $\mathrm{i}$ & $a-b$ & - & - \\
\hline Phacus sp. & - & - & - & 1 & - & - & - & - & - & 1 & - & - & - & - & - & - & - \\
\hline $\begin{array}{l}\text { *Trachelomonas hispida } \\
\text { (Perty) F. Stein }\end{array}$ & - & - & - & - & - & - & - & - & 1 & - & 1 & 2.0 & - & $\mathrm{i}$ & $\mathrm{b}$ & - & - \\
\hline Heterokontophyta & & & & & & & & & & & & & & & & & \\
\hline $\begin{array}{l}\text { *Dinobryon divergens } \\
\text { O.E. Imhof }\end{array}$ & - & - & - & - & 2 & - & - & - & - & - & - & 1.8 & ind & $\mathrm{i}$ & $\mathrm{o}-\mathrm{a}$ & - & - \\
\hline *Ophiocytium majus Nägeli & - & - & - & - & - & - & - & - & - & - & 1 & 1.5 & - & - & o-b & - & - \\
\hline Bacillariophyta & & & & & & & & & & & & & & & & & \\
\hline $\begin{array}{l}\text { Achnanthes inflata } \\
\text { (Kützing) Grunow }\end{array}$ & - & - & - & - & - & - & 1 & - & - & - & - & - & - & $\mathrm{i}$ & - & - & - \\
\hline Achnanthes sp. & - & - & - & - & 3 & - & - & - & - & - & - & - & - & - & - & - & - \\
\hline $\begin{array}{l}\text { *Achnanthidium } \\
\text { minutissimum (Kützing) } \\
\text { Czarnecki }\end{array}$ & $3-6$ & $1-6$ & $2-6$ & $1-4$ & - & 3 & $1-3$ & - & $2-6$ & - & - & 2.2 & alf & $\mathrm{i}$ & $\mathrm{b}$ & ate & hy \\
\hline $\begin{array}{l}\text { Amphora coffeaeformis } \\
\text { (C. Agardh) Kützing }\end{array}$ & - & - & - & - & - & - & - & - & - & 1 & - & - & alf & $\mathrm{mh}$ & $\mathrm{a}$ & ate & $\mathrm{e}$ \\
\hline $\begin{array}{l}\text { *Amphora ovalis } \\
\text { (Kützing) Kützing }\end{array}$ & 2 & 1 & $1-2$ & 1 & $1-2$ & - & $1-3$ & 1 & 1 & 2 & - & 2.7 & alf & $\mathrm{i}$ & $a-b$ & ate & $\mathrm{e}$ \\
\hline $\begin{array}{l}\text { *Amphora pediculus } \\
\text { (Kützing) Grunow ex A. } \\
\text { Schmidt }\end{array}$ & 2 & $1-3$ & 1 & 1 & 1 & - & 1 & - & 2 & 3 & - & 1.8 & alf & $\mathrm{i}$ & o-a & ate & $\mathrm{e}$ \\
\hline Amphora sp. & - & - & 2 & - & - & - & - & - & 1 & - & - & - & - & - & - & - & - \\
\hline *Amphora veneta Kützing & $1-2$ & - & - & - & - & - & - & - & $2-3$ & - & - & 1.0 & alf & $\mathrm{i}$ & $\mathrm{o}$ & ate & $\mathrm{e}$ \\
\hline $\begin{array}{l}\text { *Aneumastus tuscula } \\
\text { (Ehrenberg) D.G. Mann } \\
\text { \& A.J. Stickle in Round et al. }\end{array}$ & - & - & - & - & 1 & - & - & - & - & - & - & 0.7 & alf & $\mathrm{i}$ & $0-x$ & - & hy \\
\hline $\begin{array}{l}\text { *Anomoeoneis } \\
\text { sphaerophora } \text { E. Pfitzer }\end{array}$ & - & - & - & - & - & - & 2 & - & 1 & - & - & 0.8 & alb & hl & $x-b$ & ate & $\mathrm{e}$ \\
\hline *Aulacoseira granulata & - & - & - & - & 1 & - & 1 & - & - & 1 & - & 2.4 & alf & $\mathrm{i}$ & $\mathrm{b}-\mathrm{a}$ & ate & $\mathrm{e}$ \\
\hline
\end{tabular}


Table 4 - Continued

\begin{tabular}{|c|c|c|c|c|c|c|c|c|c|c|c|c|c|c|c|c|c|}
\hline (Ehrenberg) Simonsen & & & & & & & & & & & & & & & & & \\
\hline $\begin{array}{l}\text { *Bacillaria paradoxa } \\
\text { J.F. Gmelin }\end{array}$ & - & - & - & - & - & - & 2 & - & - & - & - & - & - & - & - & - & - \\
\hline $\begin{array}{l}\text { Brachysira brebissonii } \\
\text { R. Ross }\end{array}$ & - & 1 & - & - & 1 & - & - & - & - & - & - & 1.0 & acf & oh & o & - & - \\
\hline $\begin{array}{l}\text { Campylodiscus } \\
\text { hibernicus } \text { Ehrenberg }\end{array}$ & 1 & - & - & - & - & - & - & - & - & - & - & 1.3 & ind & $\mathrm{i}$ & o & - & e \\
\hline $\begin{array}{l}\text { *Cocconeis neodiminuta } \\
\text { Krammer }\end{array}$ & 3 & - & - & - & - & - & - & - & 2 & - & - & 1.0 & alb & $\mathrm{i}$ & o & - & - \\
\hline $\begin{array}{l}{ }^{*} \text { Cocconeis placentula } \text { Ehren- } \\
\text { berg }\end{array}$ & $1-5$ & $1-6$ & $4-5$ & $1-5$ & $1-5$ & $4-6$ & $1-3$ & $3-4$ & 3 & - & $1-6$ & 1.4 & alf & $\mathrm{i}$ & o-b & ate & e \\
\hline $\begin{array}{l}\text { *Craticula cuspidata } \\
\text { (Kutzing) D.G. } \\
\text { Mann in Round, Crawford \& } \\
\text { Mann }\end{array}$ & - & - & - & - & - & - & - & - & - & - & 3 & 1.0 & alf & $\mathrm{i}$ & o & wo & - \\
\hline $\begin{array}{l}\text { Cyclotella antiqua } \\
\text { W. Smith }\end{array}$ & - & - & - & - & - & - & - & - & 1 & - & - & & acf & $\mathrm{hb}$ & 0 & ats & ot \\
\hline $\begin{array}{l}\text { *Cyclotella meneghiniana } \\
\text { Kützing }\end{array}$ & 2 & 1 & - & - & $1-2$ & - & - & - & $3-4$ & $3-4$ & - & 1.8 & alf & hl & o-a & hne & e \\
\hline $\begin{array}{l}\text { *Cymatopleura elliptica } \\
\text { (Brébisson) W. Smith }\end{array}$ & 1 & - & - & - & 1 & - & - & 1 & - & - & - & 1.7 & alf & $\mathrm{i}$ & b-o & ate & e \\
\hline $\begin{array}{l}\text { *Cymatopleura solea } \\
\text { (Brébisson) W. Smith }\end{array}$ & 1 & - & - & - & 1 & 1 & - & - & - & - & - & 1.0 & alf & $\mathrm{i}$ & o & ate & e \\
\hline *Cymbella affinis Kützing & 3 & - & - & - & - & - & - & - & - & - & - & 1.7 & alf & $\mathrm{i}$ & b-o & ats & $\mathrm{e}$ \\
\hline $\begin{array}{l}\text { Cymbella lanceolata } \\
\text { (Ehrenberg) Kirchner }\end{array}$ & - & - & - & - & 1 & 3 & 3 & - & - & - & - & 1.3 & alf & $\mathrm{i}$ & 0 & ats & hy \\
\hline $\begin{array}{l}\text { Cymbella naviculiformis } \\
\text { (Auerswald) Cleve }\end{array}$ & - & 2 & - & - & - & - & - & - & - & - & - & 1.3 & ind & $\mathrm{i}$ & o & ate & $\mathrm{e}$ \\
\hline Cymbella sp. & - & - & - & $1-2$ & 1 & - & 2 & - & - & - & - & - & - & - & - & - & - \\
\hline $\begin{array}{l}\text { Cymbella tumida } \\
\text { (Brébisson in Kützing) } \\
\text { van Heurck }\end{array}$ & - & - & - & - & $1-3$ & - & - & - & - & - & - & 0.2 & alf & $\mathrm{i}$ & $x$ & ats & m-e \\
\hline $\begin{array}{l}\text { Cymbella turgidula } \\
\text { Grunow in A. Schmidt et al. }\end{array}$ & - & $1-2$ & - & $1-2$ & - & 1 & - & - & $2-5$ & - & - & - & ind & - & - & - & - \\
\hline $\begin{array}{l}\text { *Diatoma hyemale } \\
\text { (Roth) Heiberg }\end{array}$ & 2 & - & 5 & $2-3$ & $1-6$ & 4 & 1 & $1-4$ & - & - & - & 1.7 & ind & $\mathrm{hb}$ & b-o & ats & - \\
\hline $\begin{array}{l}\text { *Diatoma vulgaris } \\
\text { Bory de Saint-Vincent }\end{array}$ & $1-3$ & - & - & $2-6$ & $1-2$ & - & - & - & - & - & - & 2.4 & ind & $\mathrm{i}$ & b-a & ate & m-e \\
\hline $\begin{array}{l}\text { Diploneis oblongella } \\
\text { (Nägeli in Kützing) } \\
\text { Cleve-Euler in } \\
\text { Cleve-Euler (\& Osvald) }\end{array}$ & - & - & - & 1 & - & - & - & - & - & - & - & 1.9 & alf & $\mathrm{i}$ & o-a & ats & - \\
\hline $\begin{array}{l}\text { *Discostella stelligera } \\
\text { (Cleve \& Grunow) Houk \& } \\
\text { Klee }\end{array}$ & - & - & - & - & - & - & - & - & - & 3 & - & 0.1 & ind & $\mathrm{i}$ & $x$ & - & - \\
\hline $\begin{array}{l}\text { *Ellerbeckia arenaria } \\
\text { (Moore) R.M. Crawford }\end{array}$ & 2 & 1 & - & - & - & - & - & - & - & - & - & 1.8 & alf & $\mathrm{i}$ & o-a & ats & ot \\
\hline $\begin{array}{l}\text { Encyonema caespitosum } \\
\text { Kützing }\end{array}$ & 3 & - & - & - & - & - & - & - & - & - & - & - & - & $\mathrm{i}$ & b-a & & hy \\
\hline $\begin{array}{l}\text { *Encyonema minutum } \\
\text { (Hilse in Rabenhorst) } \\
\text { D.G. Mann in Round, } \\
\text { Crawford \& Mann }\end{array}$ & $1-2$ & - & - & - & $1-2$ & 2 & $2-3$ & - & $1-3$ & - & - & 1.3 & ind & $\mathrm{i}$ & o & - & - \\
\hline $\begin{array}{l}\text { *Encyonema silesiacum } \\
\text { (Bleisch) D.G. Mann in } \\
\text { Round, Crawford \& Mann }\end{array}$ & - & - & - & - & - & - & 2 & - & - & - & - & 1.33 & ind & $\mathrm{i}$ & X-o & - & \\
\hline $\begin{array}{l}\text { Entomoneis costata } \\
\text { (Hustedt) Reimer }\end{array}$ & - & - & - & - & 1 & - & - & - & - & - & - & - & alf & - & - & - & - \\
\hline $\begin{array}{l}\text { *Epithemia adnata } \\
\text { (Kützing) Brébisson }\end{array}$ & 1 & - & - & - & - & - & - & - & - & - & - & 2.5 & alb & $\mathrm{i}$ & b-a & ats & m-e \\
\hline $\begin{array}{l}\text { Epithemia argus } \\
\text { (Ehrenberg) Kützing }\end{array}$ & - & - & - & - & - & - & - & 1 & - & - & - & 1.8 & ind & $\mathrm{i}$ & o & - & $\mathrm{m}$ \\
\hline *Epithemia sorex Kützing & - & - & - & - & - & - & 1 & $1-3$ & - & - & - & 1.9 & alf & $\mathrm{i}$ & o-a & ats & $\mathrm{e}$ \\
\hline $\begin{array}{l}\text { Epithemia turgida } \\
\text { (Ehrenberg) Kützing }\end{array}$ & - & 3 & - & - & $1-2$ & - & - & 1 & - & - & - & 1.1 & alf & $\mathrm{i}$ & o & ats & m-e \\
\hline $\begin{array}{l}\text { Eucocconeis flexella } \\
\text { (Kützing) Meister }\end{array}$ & - & - & - & - & - & 1 & - & - & - & - & - & 1.5 & ind & $\mathrm{mh}$ & o-b & ats & ot \\
\hline
\end{tabular}




\begin{tabular}{|c|c|c|c|c|c|c|c|c|c|c|c|c|c|c|c|c|c|}
\hline $\begin{array}{l}\text { *Fallacia pygmaea } \\
\text { (Kützing) A.J. } \\
\text { Stickle \& D.G. Mann } \\
\text { in Round, Crawford \& Mann }\end{array}$ & 1 & 1 & - & - & - & - & - & 1 & - & - & - & 1.7 & alf & $\mathrm{mh}$ & b-o & hne & $\mathrm{e}$ \\
\hline $\begin{array}{l}\text { Fallacia subhamulata } \\
\text { (Grunow in van Heurck) } \\
\text { D.G. Mann in Round, } \\
\text { Crawford \& Mann }\end{array}$ & - & - & - & 3 & - & - & - & - & - & - & - & - & - & - & - & - & - \\
\hline $\begin{array}{l}\text { *Fragilaria capucina } \\
\text { var. vaucheriae } \\
\text { (Kützing) Lange-Bertalot }\end{array}$ & - & - & - & - & - & - & - & - & 1 & 1 & - & 1.5 & alf & $\mathrm{i}$ & o-b & - & - \\
\hline $\begin{array}{l}\text { Fragilariforma virescens } \\
\text { (Ralfs) D.M. } \\
\text { Williams \& Round }\end{array}$ & - & 1 & - & - & - & - & - & - & $2-3$ & - & - & 1.3 & neu & $\mathrm{i}$ & o & ats & o-m \\
\hline $\begin{array}{l}\text { Frustulia rhomboides } \\
\text { (Ehrenberg) De Toni }\end{array}$ & - & - & - & - & - & - & 1 & - & - & - & - & 0.9 & acf & $\mathrm{hb}$ & $x-b$ & ats & ot \\
\hline $\begin{array}{l}\text { *Frustulia vulgaris } \\
\text { (Thwaites) De Toni }\end{array}$ & - & 1 & - & - & 2 & - & - & - & - & - & - & 0.9 & alf & $\mathrm{i}$ & $\mathrm{x}-\mathrm{b}$ & ate & m-e \\
\hline $\begin{array}{l}{ }^{*} \text { Gomphonema } \\
\text { affine Kützing }\end{array}$ & - & - & - & - & 2 & - & $1-4$ & - & - & - & - & 1.5 & - & - & o-b & - & - \\
\hline $\begin{array}{l}* \text { Gomphonema } \\
\text { angustatum (Kützing) } \\
\text { Rabenhorst }\end{array}$ & - & - & - & - & $3-4$ & - & $5-6$ & - & - & - & 2 & 2.0 & alf & $\mathrm{i}$ & $\mathrm{b}$ & - & - \\
\hline $\begin{array}{l}{ }^{*} \text { Gomphonema insigne } \\
\text { Gregory }\end{array}$ & 3 & - & - & - & - & - & - & - & - & - & - & - & - & $\mathrm{i}$ & - & - & - \\
\hline $\begin{array}{l}\text { Gomphonema intricatum } \\
\text { Kützing }\end{array}$ & - & 1 & - & - & 1 & - & 3 & - & - & - & - & 0.4 & ind & $\mathrm{i}$ & $\mathrm{x}-\mathrm{O}$ & - & - \\
\hline $\begin{array}{l}\text { *Gomphonema minutum } \\
\text { (C. Agardh) C. Agardh }\end{array}$ & - & - & - & - & 1 & - & - & - & - & - & - & - & alf & oh & o-b & - & e \\
\hline $\begin{array}{l}\text { *Gomphonema olivaceum } \\
\text { (Hornemann) Brébisson }\end{array}$ & $3-6$ & - & - & - & - & - & - & - & 2 & 1 & - & 2.5 & alf & $\mathrm{i}$ & b-a & ate & $\mathrm{e}$ \\
\hline $\begin{array}{l}\text { *Gomphonema parvulum } \\
\text { (Kützing) Kützing }\end{array}$ & $1-3$ & $1-3$ & $2-4$ & $1-6$ & $1-5$ & 4 & $1-5$ & - & $1-6$ & $1-3$ & $3-6$ & 0.1 & ind & $\mathrm{i}$ & $\mathrm{x}$ & hne & $\mathrm{e}$ \\
\hline Gomphonema sp. & 3 & - & - & - & - & - & $2-3$ & - & - & - & - & - & - & - & - & - & - \\
\hline $\begin{array}{l}* \text { *Gomphonema truncatum } \\
\text { Ehrenberg }\end{array}$ & 2 & 1 & - & - & - & - & 2 & - & 5 & - & - & 0.7 & alf & i & o-x & ats & m-e \\
\hline $\begin{array}{l}\text { *Gomphonema vibrio } \\
\text { var. intricatum (Kützing) } \\
\text { Playfair }\end{array}$ & $3-4$ & - & - & 2 & 1 & $4-5$ & 4 & - & - & - & - & 1.4 & ind & $\mathrm{i}$ & o-b & ats & ot \\
\hline $\begin{array}{l}\text { Gomphonemopsis exigua } \\
\text { (Kützing) Medlin }\end{array}$ & - & - & - & - & - & - & 1 & - & - & - & - & - & - & $\mathrm{hl}$ & - & - & - \\
\hline $\begin{array}{l}\text { Gyrosigma acuminatum } \\
\text { (Kützing) Rabenhorst }\end{array}$ & 1 & $1-4$ & - & $1-3$ & $1-3$ & - & $1-3$ & 1 & 2 & - & 1 & 0.7 & alf & $\mathrm{i}$ & o-x & ate & e \\
\hline $\begin{array}{l}\text { *Hantzschia amphioxys } \\
\text { (Ehrenberg) Grunow } \\
\text { in Cleve \& Grunow }\end{array}$ & - & 1 & - & 1 & - & - & - & - & 2 & 4 & - & 1.7 & neu & i & b-o & ate & hy \\
\hline $\begin{array}{l}\text { Luticola muticopsis } \\
\text { (Van Heurck) D.G. Mann }\end{array}$ & - & - & - & - & 4 & - & - & - & - & - & - & - & - & - & - & - & - \\
\hline *Melosira varians C. Agardh & $2-4$ & $1-5$ & 1 & 5 & $1-5$ & 3 & $2-5$ & - & $3-6$ & 2 & 1 & 2.7 & alf & $\mathrm{hl}$ & $a-b$ & hne & $\mathrm{e}$ \\
\hline $\begin{array}{l}\text { *Meridion circulare } \\
\text { (Greville) C. Agardh }\end{array}$ & 1 & $1-3$ & 2 & 3 & - & - & - & - & $1-6$ & 1 & - & 1.5 & alf & $\mathrm{i}$ & o-b & ate & hy \\
\hline *Navicula angusta Grunow & - & - & - & - & 4 & 4 & - & - & - & - & - & - & acf & $\mathrm{hl}$ & o & ats & ot \\
\hline $\begin{array}{l}\text { *Navicula cryptocephala } \\
\text { Kützing }\end{array}$ & 3 & - & - & - & $1-2$ & - & 1 & - & $2-3$ & - & - & 2.7 & alf & $\mathrm{i}$ & $\mathrm{a}$ & ate & hy \\
\hline Navicula exigua Gregory & $1-2$ & $1-2$ & 3 & - & 3 & - & 2 & 2 & $2-6$ & $3-4$ & - & 0.5 & alf & $\mathrm{i}$ & $\mathrm{x}-\mathrm{O}$ & ats & $\mathrm{e}$ \\
\hline Navicula gibbula Cleve & 1 & - & - & - & - & - & - & - & - & - & - & - & neu & $\mathrm{i}$ & - & - & - \\
\hline $\begin{array}{l}\text { Navicula pupula var. } \\
\text { rectangularis (W. Gregory) } \\
\text { Cleve \& Grunov }\end{array}$ & - & - & 4 & - & - & - & - & - & - & - & - & - & ind & $\mathrm{hl}$ & - & ate & m-e \\
\hline *Navicula radiosa Kützing & 3 & - & - & - & - & - & - & - & - & - & - & 1.1 & ind & $\mathrm{i}$ & o & ate & m-e \\
\hline $\begin{array}{l}\text { Navicula recens } \\
\text { (Lange-Bertalot) } \\
\text { Lange-Bertalot in } \\
\text { Krammer \& Lange-Bertalot }\end{array}$ & 3 & $1-4$ & $3-4$ & $3-6$ & $2-6$ & 4 & $1-4$ & 2 & 3 & 5 & - & - & alf & i & o-b & - & $\mathrm{e}$ \\
\hline $\begin{array}{l}\text { *Navicula rhynchocephala } \\
\text { Kützing }\end{array}$ & $3-4$ & $2-6$ & - & - & $2-3$ & 4 & $1-6$ & - & - & - & - & 2.3 & alf & hl & b & ate & hy \\
\hline
\end{tabular}


Table 4 - Continued

\begin{tabular}{|c|c|c|c|c|c|c|c|c|c|c|c|c|c|c|c|c|c|}
\hline Navicula sp. & $2-3$ & $2-6$ & $3-6$ & $4-6$ & $1-6$ & 1 & $1-4$ & 2 & $3-6$ & 5 & 3 & - & - & - & - & - & - \\
\hline $\begin{array}{l}\text { *Navicula tripunctata } \\
\text { (O.F. Müller) Bory }\end{array}$ & 3 & - & 2 & $2-3$ & - & - & - & - & - & - & - & 2.3 & ind & $\mathrm{i}$ & $\mathrm{b}$ & ate & e \\
\hline *Navicula veneta Kützing & - & - & - & - & 1 & - & - & - & - & - & - & 1.1 & alf & hl & $\mathrm{X}-\mathrm{O}$ & ate & $\mathrm{e}$ \\
\hline $\begin{array}{l}\text { *Navicula viridula } \\
\text { (Kützing) Kützing }\end{array}$ & 3 & - & - & - & - & - & - & - & - & - & - & 1.3 & alf & hl & o & ate & $\mathrm{e}$ \\
\hline $\begin{array}{l}\text { Neidium iridis (Ehrenberg) } \\
\text { Cleve }\end{array}$ & - & - & 1 & - & - & - & - & - & 1 & - & - & 0.6 & ind & $\mathrm{hb}$ & $0-x$ & ats & $\mathrm{m}$ \\
\hline $\begin{array}{l}\text { *Nitzschia acicularis } \\
\text { (Kützing) W. Smith }\end{array}$ & - & 2 & - & - & 1 & - & - & - & $1-4$ & 1 & - & 1.5 & alf & $\mathrm{i}$ & o-b & hce & $\mathrm{e}$ \\
\hline $\begin{array}{l}\text { *Nitzschia amphibian } \\
\text { Grunow }\end{array}$ & - & - & - & - & 1 & - & - & - & - & - & - & 1.3 & alf & i & o & hne & $\mathrm{e}$ \\
\hline $\begin{array}{l}\text { *Nitzschia dissipata } \\
\text { (Kützing) Grunow }\end{array}$ & 1 & - & 5 & - & - & 2 & - & - & $4-2$ & - & - & 0.2 & alf & $\mathrm{i}$ & $\mathrm{x}$ & ate & m-e \\
\hline $\begin{array}{l}\text { Nitzschia filiformis } \\
\text { (W. Smith) Hustedt }\end{array}$ & 2 & - & 3 & 3 & $1-5$ & - & $2-4$ & - & $1-6$ & - & - & 0.3 & alf & hl & $\mathrm{x}$ & hne & e \\
\hline $\begin{array}{l}\text { Nitzschia fonticola } \\
\text { (Grunow) Grunow } \\
\text { in Van Heurck }\end{array}$ & - & - & 2 & - & - & - & 1 & - & 1 & - & - & 1.5 & alf & oh & o-b & ate & m-e \\
\hline $\begin{array}{l}\text { *Nitzschia linearis } \\
\text { (Agardh) W. Smith }\end{array}$ & 3 & 1 & - & 2 & $1-2$ & - & $1-3$ & - & 2 & - & - & 0.0 & alf & $\mathrm{i}$ & $\mathrm{x}$ & ate & m-e \\
\hline $\begin{array}{l}\text { *Nitzschia palea } \\
\text { (Kützing) W. Smith }\end{array}$ & $1-2$ & $3-4$ & $1-2$ & $2-3$ & $1-3$ & 5 & $1-6$ & 2 & $2-6$ & 1 & - & 0.7 & ind & $\mathrm{i}$ & $0-\mathrm{x}$ & hce & he \\
\hline $\begin{array}{l}{ }^{*} \text { Nitzschia sigmoidea } \\
\text { (Nitzsch) W. Smith }\end{array}$ & - & - & - & - & 1 & - & 3 & - & - & - & - & 1.1 & alf & $\mathrm{i}$ & o & ate & $\mathrm{e}$ \\
\hline Nitzschia solita Hustedt & - & - & - & - & - & - & - & 1 & $1-2$ & - & - & - & alf & $\mathrm{mh}$ & $a-b$ & - & $\mathrm{e}$ \\
\hline Nitzschia sp. & $1-4$ & 1 & 3 & $2-5$ & $2-5$ & 6 & 3 & $1-3$ & $2-5$ & 1 & - & - & - & - & - & - & - \\
\hline $\begin{array}{l}\text { *Nitzschia umbonata } \\
\text { (Ehrenberg) } \\
\text { Lange-Bertalot }\end{array}$ & - & - & - & - & 3 & - & - & - & - & - & - & 1.7 & - & - & b-o & - & - \\
\hline $\begin{array}{l}\text { *Nitzschia vermicularis } \\
\text { (Kützing) Hantzsch } \\
\text { in Rabenhorst }\end{array}$ & 1 & 1 & - & - & $1-4$ & - & 4 & - & - & - & - & 1.3 & alf & $\mathrm{i}$ & o & - & hy \\
\hline $\begin{array}{l}\text { *Planothidium lanceolatum } \\
\text { (Brébisson ex Kützing) } \\
\text { Lange-Bertalot }\end{array}$ & 1 & 1 & - & - & 2 & - & 1 & - & 1 & - & - & 0.75 & alf & $\mathrm{i}$ & o-x & - & - \\
\hline $\begin{array}{l}\text { Pleurosira laevis } \\
\text { (Ehrenberg) Compère }\end{array}$ & - & - & - & - & $1-3$ & - & 3 & - & - & - & - & - & alf & $\mathrm{mh}$ & o & - & $\mathrm{e}$ \\
\hline $\begin{array}{l}\text { Reimeria sinuata } \\
\text { (Gregory) } \\
\text { Kociolek \& Stoermer }\end{array}$ & - & - & - & - & 1 & - & 1 & - & - & - & - & - & ind & $\mathrm{i}$ & - & - & - \\
\hline $\begin{array}{l}\text { *Rhoicosphenia abbreviate } \\
\text { (C. Agardh) Lange-Bertalot }\end{array}$ & $1-4$ & $1-6$ & $3-5$ & $1-3$ & $1-6$ & $3-4$ & $2-6$ & 3 & 3 & - & - & 0.5 & alf & $\mathrm{i}$ & X-o & ate & $\mathrm{e}$ \\
\hline $\begin{array}{l}\text { *Rhopalodia gibba } \\
\text { (Ehrenberg) O.F. Müller }\end{array}$ & - & - & - & - & - & - & - & $2-4$ & - & - & - & 0.4 & $\mathrm{alb}$ & $\mathrm{i}$ & X-o & - & - \\
\hline $\begin{array}{l}\text { Rhopalodia musculus } \\
\text { (Kützing) O.F. Müller }\end{array}$ & - & - & - & 1 & - & - & - & - & - & - & - & - & alb & $\mathrm{mh}$ & $\mathrm{x}$ & - & - \\
\hline $\begin{array}{l}\text { Sellaphora parapupula } \\
\text { Lange-Bertalot }\end{array}$ & - & - & - & - & 1 & - & - & - & - & - & - & - & - & - & - & - & - \\
\hline $\begin{array}{l}\text { *Sellaphora pupula } \\
\text { (Kützing) Mereschkovsky }\end{array}$ & 1 & - & 3 & - & 1 & - & 1 & - & 1 & 1 & - & 0.5 & ind & $\mathrm{hl}$ & $x-0$ & ate & m-e \\
\hline Stauroneis anceps Ehrenberg & - & - & - & - & - & - & - & - & 1 & - & - & 0.3 & ind & $\mathrm{i}$ & $\mathrm{x}$ & ate & m-e \\
\hline $\begin{array}{l}\text { *Staurosira construens } \\
\text { Ehrenberg }\end{array}$ & 1 & - & - & - & - & - & - & - & - & - & - & 1.3 & alf & $\mathrm{i}$ & o & - & - \\
\hline $\begin{array}{l}\text { Staurosirella pinnata } \\
\text { (Ehrenberg) D.M. } \\
\text { Williams \& Round }\end{array}$ & - & - & - & - & - & - & - & - & - & 1 & - & - & alf & hl & b-a & ate & o-e \\
\hline $\begin{array}{l}\text { *Stephanodiscus hantzschii } \\
\text { Grunow }\end{array}$ & - & - & - & - & 1 & - & - & - & - & - & - & 2.7 & alf & $\mathrm{i}$ & $a-b$ & hne & he \\
\hline *Surirella angusta Kützing & 1 & - & - & - & 1 & - & - & - & 2 & - & - & 1.1 & alf & $\mathrm{i}$ & o & ate & $\mathrm{e}$ \\
\hline Surirella linearis W. Smith & 1 & 3 & - & $1-3$ & - & - & - & - & $1-3$ & - & - & 1.4 & ind & $\mathrm{i}$ & o-b & - & o-m \\
\hline $\begin{array}{l}\text { *Surirella minuta } \\
\text { Brébisson in Kützing }\end{array}$ & $2-3$ & 1 & - & - & $1-2$ & 1 & - & - & $2-6$ & 2 & - & 1.85 & ind & $\mathrm{i}$ & o-a & - & ot \\
\hline *Surirella ovalis Brébisson & - & - & - & $1-4$ & 1 & - & 1 & - & $1-3$ & - & - & - & alf & $\mathrm{mh}$ & o & ate & $\mathrm{e}$ \\
\hline Surirella robusta Ehrenberg & - & - & - & - & 1 & - & - & 1 & - & - & - & 1.7 & ind & $\mathrm{hb}$ & b-o & - & hy \\
\hline
\end{tabular}


Table 4 - Continued

\begin{tabular}{|c|c|c|c|c|c|c|c|c|c|c|c|c|c|c|c|c|c|}
\hline *Surirella spiralis Kützing & 1 & - & - & - & - & - & - & - & - & - & - & 1.0 & neu & $\mathrm{i}$ & 0 & ats & ot \\
\hline $\begin{array}{l}\text { *Surirella splendida } \\
\text { (Ehrenberg) Kützing }\end{array}$ & - & - & - & - & - & - & 1 & - & - & - & - & 1.5 & alf & $\mathrm{i}$ & $o-b$ & - & $m-e$ \\
\hline $\begin{array}{l}\text { Surirella tenera W. } \\
\text { Gregory }\end{array}$ & 2 & - & - & 1 & 1 & - & 1 & - & - & - & - & 1.0 & alf & $\mathrm{i}$ & 0 & - & $\mathrm{e}$ \\
\hline $\begin{array}{l}\text { *Tryblionella angustata } \\
\text { W. Smith }\end{array}$ & - & - & - & - & 1 & - & - & - & - & - & - & 0.8 & alf & $\mathrm{i}$ & $x-b$ & ats & $\mathrm{m}$ \\
\hline $\begin{array}{l}\text { *Tryblionella apiculata } \\
\text { Gregory }\end{array}$ & 1 & - & - & - & - & - & - & - & - & - & - & 2.2 & alf & $\mathrm{mh}$ & $\mathrm{b}$ & ate & $\mathrm{e}$ \\
\hline $\begin{array}{l}\text { Tryblionella levidensis } \mathrm{W} \text {. } \\
\text { Smith }\end{array}$ & - & - & - & - & 2 & - & - & - & 1 & - & 1 & 2.7 & alf & $\mathrm{hl}$ & $a-b$ & ate & $\mathrm{e}$ \\
\hline $\begin{array}{l}\text { *Ulnaria ulna (Nitzsch) P. } \\
\text { Compère in Jahn et al. }\end{array}$ & $1-5$ & $1-4$ & 1 & $1-2$ & $1-4$ & $3-4$ & $1-6$ & $1-6$ & $4-6$ & 3 & - & 1.7 & ind & $\mathrm{i}$ & $\mathrm{b}-\mathrm{o}$ & ate & hy \\
\hline Chlorophyta & & & & & & & & & & & & & & & & & \\
\hline $\begin{array}{l}\text { Acutodesmus acuminatus } \\
\text { (Lagerheim) Tsarenko }\end{array}$ & - & - & - & - & 1 & - & - & - & - & $2-3$ & - & 2.2 & ind & $\mathrm{i}$ & $\mathrm{b}$ & - & - \\
\hline $\begin{array}{l}\text { *Ankistrodesmus falcatus } \\
\text { (Corda) Ralfs }\end{array}$ & - & - & - & - & 1 & - & - & - & - & - & - & 2.1 & - & $\mathrm{hb}$ & $\mathrm{b}$ & - & - \\
\hline Chlamydomonas sp. & - & - & - & - & - & - & - & - & 1 & 3 & - & 2.8 & - & - & b-p & - & - \\
\hline $\begin{array}{l}\text { Chlamydopodium pluricoccum } \\
\text { (O.A. Korshikov) } \\
\text { H. Ettl et J. Komárek }\end{array}$ & - & - & - & 1 & - & - & 1 & - & - & - & 3 & - & - & - & - & - & - \\
\hline $\begin{array}{l}\text { *Cladophora glomerata } \\
\text { (Linnaeus) Kützing }\end{array}$ & 6 & $2-6$ & 6 & $2-6$ & $2-6$ & $4-6$ & 2 & $1-6$ & $3-4$ & 6 & $3-5$ & 1.7 & alf & $\mathrm{i}$ & b-o & - & - \\
\hline $\begin{array}{l}\text { Closteriopsis acicularis } \\
\text { (Chodat) J.H. } \\
\text { Belcher \& Swale }\end{array}$ & - & - & - & - & - & - & - & - & 2 & 1 & - & 1.9 & - & $\mathrm{i}$ & o-a & - & - \\
\hline $\begin{array}{l}\text { *Coelastrum astroideum } \\
\text { De Notaris }\end{array}$ & - & - & - & - & - & - & - & - & 1 & - & $1-2$ & 2.0 & - & - & $\mathrm{b}$ & - & - \\
\hline $\begin{array}{l}\text { *Coelastrum microporum } \\
\text { Nägeli }\end{array}$ & - & - & - & - & 1 & - & - & - & - & 1 & 1 & 2.1 & ind & i & b & - & - \\
\hline 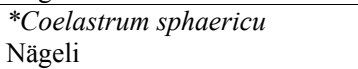 & - & - & - & - & 1 & - & - & - & - & 3 & - & 1.0 & - & $\mathrm{i}$ & 0 & - & - \\
\hline $\begin{array}{l}{ }^{*} \text { Crucigenia tetrapedia } \\
\text { (Kirchner) W. } \\
\text { West \& G.S. West }\end{array}$ & - & - & - & - & 1 & - & - & - & - & - & - & 1.9 & ind & $\mathrm{i}$ & o-a & - & - \\
\hline $\begin{array}{l}\text { *Desmodesmus abundans } \\
\text { (Kirchner) E. Hegewald }\end{array}$ & - & - & - & - & 1 & - & - & - & - & 1 & - & 1.8 & - & - & o-a & - & - \\
\hline $\begin{array}{l}\text { *Desmodesmus armatus } \\
\text { (R. Chodat) E. Hegewald } \\
\text { var. armatus }\end{array}$ & - & - & - & - & 2 & - & - & - & 1 & - & $1-2$ & 1.9 & - & - & o-a & - & - \\
\hline $\begin{array}{l}\text { *Desmodesmus armatus var. } \\
\text { bicaudatus (Guglielmetti) E. } \\
\text { Hegewald }\end{array}$ & - & - & - & - & - & - & - & - & - & - & 2 & 2.0 & - & - & $\mathrm{b}$ & - & - \\
\hline $\begin{array}{l}\text { Desmodesmus armatus } \\
\text { var. spinosus (Fritsch \& Rich) } \\
\text { E. Hegewald }\end{array}$ & - & - & - & - & - & - & - & - & 1 & - & - & - & - & - & $\mathrm{b}$ & - & - \\
\hline $\begin{array}{l}\text { *Desmodesmus intermedius } \\
\text { (R. Chodat) E. Hegewald }\end{array}$ & - & - & - & - & - & - & - & - & - & 1 & - & - & - & - & $\mathrm{b}$ & - & - \\
\hline $\begin{array}{l}\text { *Desmodesmus maximus } \\
\text { (W. West \& G. S. West) } \\
\text { E. Hegewald }\end{array}$ & 1 & - & - & - & 11 & - & - & - & - & - & - & 2.0 & - & - & $\mathrm{b}$ & - & - \\
\hline $\begin{array}{l}\text { *Desmodesmus opoliensis } \\
\text { (P. Richter) E. Hegewald }\end{array}$ & 1 & - & - & - & 1 & - & - & - & - & - & - & 2.2 & - & - & $\mathrm{b}$ & - & - \\
\hline $\begin{array}{l}\text { *Desmodesmus perforatus } \\
\text { (Lemmermann) E. } \\
\text { Hegewald }\end{array}$ & - & - & - & - & - & - & - & - & - & - & 1 & - & - & - & - & - & - \\
\hline $\begin{array}{l}\text { *Dictyosphaerium } \\
\text { Pulchellum H.C. Wood }\end{array}$ & - & - & - & - & 1 & - & - & - & - & $1-2$ & - & 2.3 & ind & $\mathrm{i}$ & $\mathrm{b}$ & - & - \\
\hline Diplostauron sp. & - & - & - & - & - & - & - & - & - & 1 & - & - & - & - & - & - & - \\
\hline Gloeocystis sp. & 1 & - & - & - & - & - & - & - & - & - & - & - & - & - & - & - & \\
\hline $\begin{array}{l}\text { *Golenkinia radiata } \\
\text { Chodat }\end{array}$ & - & - & - & - & 1 & - & - & - & - & - & - & 1.9 & - & $\mathrm{i}$ & o-a & - & - \\
\hline $\begin{array}{l}\text { *Monoraphidium arcuatum } \\
\text { (Korshikov) Hindák }\end{array}$ & - & - & - & - & - & - & - & - & - & 1 & - & 2.1 & - & - & $\mathrm{b}$ & - & - \\
\hline $\begin{array}{l}\text { *Monoraphidium contortum } \\
\text { (Thuret) }\end{array}$ & - & - & - & - & - & - & - & - & 1 & - & 1 & 2.2 & - & - & $\mathrm{b}$ & - & - \\
\hline
\end{tabular}


Table 4 - Continued

\begin{tabular}{|c|c|c|c|c|c|c|c|c|c|c|c|c|c|c|c|c|c|}
\hline Komàrková-Legnerová & & & & & & & & & & & & & & & & & \\
\hline $\begin{array}{l}\text { *Monoraphidium griffithii } \\
\text { (Berkeley) Komárk- } \\
\text { ová-Legnerová }\end{array}$ & - & 1 & - & - & - & - & - & - & - & $1-2$ & - & 2.2 & - & - & b & - & - \\
\hline $\begin{array}{l}\text { *Monoraphidium irregulare } \\
\text { (G.M.Smith) Komárk- } \\
\text { ová-Legnerová }\end{array}$ & - & - & - & - & - & - & - & - & - & 1 & - & - & - & $\mathrm{i}$ & - & - & - \\
\hline $\begin{array}{l}\text { Monoraphidium obtusum } \\
\text { (Korshikov) } \\
\text { Komárková-Legnerová }\end{array}$ & - & - & - & - & 1 & - & - & - & - & - & - & 1.2 & - & - & o & - & - \\
\hline Oedogonium sp. & - & 4 & - & - & 1 & - & $1-4$ & 1 & $1-2$ & - & - & - & - & - & - & - & - \\
\hline $\begin{array}{l}\text { *Oocystis submarina } \\
\text { Lagerheim }\end{array}$ & - & - & - & - & - & - & - & - & - & 3 & - & - & - & $\mathrm{i}$ & - & - & - \\
\hline $\begin{array}{l}\text { *Pandorina elegans } \\
\text { (Ehrenberg) Dujardin }\end{array}$ & - & - & - & - & 1 & - & - & - & - & - & - & 2.2 & - & $\mathrm{i}$ & b & - & - \\
\hline $\begin{array}{l}\text { *Pandorina mora } \\
\text { (O.F. Müller) Bory de } \\
\text { Saint-Vincent }\end{array}$ & - & - & - & - & 3 & - & - & - & - & - & - & 2.1 & - & $\mathrm{i}$ & b & - & - \\
\hline $\begin{array}{l}\text { *Pediastrum duplex } \\
\text { Meyen }\end{array}$ & - & - & - & - & $1-2$ & - & - & - & - & - & - & 1.8 & ind & $\mathrm{i}$ & o-a & - & - \\
\hline $\begin{array}{l}\text { *Pediastrum simplex } \\
\text { Meyen }\end{array}$ & - & - & - & - & $1-2$ & - & - & - & - & - & $1-2$ & 1.5 & - & - & o-b & - & - \\
\hline $\begin{array}{l}\text { Planctococcus } \\
\text { sphaerocystiformis } \\
\text { O. Korshikov }\end{array}$ & - & - & - & - & - & - & - & - & - & 2 & - & - & - & - & - & - & - \\
\hline $\begin{array}{l}\text { *Scenedesmus acuminatus } \\
\text { (Lagerheim) Chodat }\end{array}$ & 1 & - & - & - & 1 & - & - & - & - & $3-4$ & - & - & - & - & - & - & - \\
\hline $\begin{array}{l}\text { Scenedesmus apiculatus } \\
\text { (W. West \& G.S. West) } \\
\text { Chodat }\end{array}$ & - & - & - & - & 1 & - & - & - & - & - & - & - & - & - & - & - & - \\
\hline $\begin{array}{l}\text { Scenedesmus } \\
\text { caudato-aculeolatus Chodat }\end{array}$ & 2 & - & - & - & - & - & - & - & - & - & - & - & - & - & - & - & - \\
\hline $\begin{array}{l}\text { Scenedesmus obliquus } \\
\text { (Turpin) Kützing }\end{array}$ & - & - & - & - & - & - & - & - & 2 & - & - & 2.0 & - & $\mathrm{i}$ & $\mathrm{b}$ & - & - \\
\hline Scenedesmus obtusus Meyen & 1 & - & - & - & 1 & - & - & - & - & - & - & 2.0 & - & - & $\mathrm{b}$ & - & - \\
\hline $\begin{array}{l}\text { Scenedesmus parvus } \\
\text { (G.M. Smith) Bourrelly } \\
\text { in Bourrelly et Manguin }\end{array}$ & - & - & - & - & 1 & - & - & - & - & - & - & - & - & - & - & - & - \\
\hline $\begin{array}{l}\text { Schroederia setigera } \\
\text { (Schröder) Lemmermann }\end{array}$ & - & - & - & - & - & - & - & - & - & 2 & - & 1.7 & - & $\mathrm{i}$ & b-o & - & - \\
\hline $\begin{array}{l}\text { Stigeoclonium carolinianum } \\
\text { Islam }\end{array}$ & - & - & - & - & 1 & - & - & - & - & - & - & - & - & - & - & - & - \\
\hline $\begin{array}{l}\text { *Stigeoclonium tenue } \\
\text { (C. Agardh) Kützing }\end{array}$ & - & - & - & - & - & - & - & - & $3-6$ & - & - & 2.8 & - & - & b-p & - & - \\
\hline $\begin{array}{l}\text { *Tetraselmis cordiformis } \\
\text { (N. Carter) Stein }\end{array}$ & - & - & - & - & - & - & - & - & 1 & - & - & 2.2 & - & - & $\mathrm{b}$ & - & - \\
\hline Tetrastrum elegans Playfair & - & - & - & - & - & - & - & - & - & 2 & 1 & 1.5 & - & $\mathrm{i}$ & o-b & - & - \\
\hline $\begin{array}{l}\text { *Tetrastrum } \\
\text { staurogeniaeforme (Schröder) } \\
\text { Lemmermann }\end{array}$ & - & - & - & - & - & - & - & - & - & 1 & - & 2.2 & - & $\mathrm{i}$ & $\mathrm{b}$ & - & - \\
\hline $\begin{array}{l}\text { *Uronema confervicola } \\
\text { Lagerheim }\end{array}$ & - & - & - & - & 1 & - & - & - & 3 & - & 2 & 1.8 & - & - & o-a & - & - \\
\hline Charophyta & & & & & & & & & & & & & & & & & \\
\hline Chara vulgaris Linnaeus & 6 & - & - & - & - & - & - & - & - & - & - & 1.1 & - & - & o & - & - \\
\hline $\begin{array}{l}\text { *Closterium acerosum } \\
\text { Ehrenberg ex Ralfs }\end{array}$ & - & - & - & - & - & 1 & 1 & 1 & 1 & - & - & 2.6 & ind & $\mathrm{i}$ & $a-b$ & - & - \\
\hline $\begin{array}{l}\text { Closterium ehrenbergii } \\
\text { Meneghini ex Ralfs }\end{array}$ & - & - & - & - & - & - & 1 & - & 1 & - & - & 1.8 & ind & $\mathrm{hb}$ & o-a & - & - \\
\hline $\begin{array}{l}\text { Closterium pronum } \\
\text { Brébisson }\end{array}$ & - & - & - & - & - & - & 1 & - & - & - & - & - & - & $\mathrm{i}$ & - & - & - \\
\hline $\begin{array}{l}\text { *Closterium ruficeps } \\
\text { C.G. Ehrenberg }\end{array}$ & - & - & - & - & - & - & - & - & 1 & - & - & 0.8 & - & - & $x-b$ & - & - \\
\hline Closterium sp. & 1 & - & - & - & - & - & - & - & - & - & - & - & - & - & - & - & - \\
\hline Coleochaete sp. & - & - & - & - & 3 & - & - & - & - & - & 2 & - & - & - & - & - & - \\
\hline $\begin{array}{l}\text { Cosmarium } \\
\text { punctulatum Brébisson }\end{array}$ & - & - & - & - & 2 & - & - & - & - & - & - & 1.3 & acf & $\mathrm{hb}$ & o & - & - \\
\hline
\end{tabular}


Table 4 - Continued

\begin{tabular}{|c|c|c|c|c|c|c|c|c|c|c|c|c|c|c|c|c|c|}
\hline Debarya sp. & - & - & - & - & 1 & - & - & - & - & - & - & - & - & - & - & - & - \\
\hline $\begin{array}{l}\text { *Koliella longiseta } \\
\text { (Vischer) Hindák }\end{array}$ & - & - & - & - & - & - & - & - & - & 2 & - & 2.1 & - & $\mathrm{i}$ & $\mathrm{b}$ & - & - \\
\hline *Mougeotia sp. & - & $4-5$ & - & - & 1 & - & $1-2$ & $5-6$ & - & - & - & 1.0 & - & - & o & - & - \\
\hline $\begin{array}{l}\text { Nitella mucronata } \\
\text { (A. Braun) Miquel in } \\
\text { H.C. Hall }\end{array}$ & - & 6 & - & - & - & - & - & - & - & - & - & 1.3 & - & - & o & - & - \\
\hline *Spirogyra sp. & $2-6$ & 6 & - & 6 & 3 & - & 2 & 5 & - & - & - & - & - & - & - & - & - \\
\hline Rhodophyta & & & & & & & & & & & & & & & & & \\
\hline $\begin{array}{l}\text { Audouinella pygmaea } \\
\text { (Kützing) Weber-van Bosse }\end{array}$ & $2-3$ & $1-4$ & - & - & $2-6$ & - & $1-3$ & - & - & - & - & 0.5 & alf & - & $\mathrm{x}-\mathrm{O}$ & - & - \\
\hline $\begin{array}{l}\text { **Batrachospermum } \\
\text { gelatinosum (Linnaeus) } \\
\text { De Candolle }\end{array}$ & - & - & - & - & - & - & 6 & - & - & - & - & 0.7 & - & - & $0-x$ & - & - \\
\hline $\begin{array}{l}\text { *Hildenbrandia rivularis } \\
\text { (Liebmann) J. Agardh }\end{array}$ & 6 & 6 & - & - & - & - & - & - & - & - & - & 0.4 & - & - & $\mathrm{X}-\mathrm{O}$ & - & - \\
\hline $\begin{array}{l}\text { Total from our data } \\
2006-2009(232)\end{array}$ & 77 & 58 & 32 & 46 & 116 & 25 & 74 & 29 & 70 & 45 & 25 & & & & & & \\
\hline $\begin{array}{l}\text { Prevoiously recorded } \\
\text { in references }[3,16-36] \\
\text { for the objects listed } \\
\text { in this Table }(227)\end{array}$ & 8 & 53 & 12 & 6 & 216 & 4 & 19 & 1 & 0 & 7 & 111 & & & & & & \\
\hline $\begin{array}{l}\text { Totals for the } \\
\text { objects studied in } \\
\text { 1887-2009 in the Upper } \\
\text { Jordan River Basin } \\
\text { (altogether 466) }\end{array}$ & 81 & 101 & 41 & 49 & 289 & 29 & 90 & 29 & 70 & 49 & 121 & & & & & & \\
\hline
\end{tabular}

Note: List of species found in the Upper Jordan River algal communities in 2006-2009 with abundance on the Korde scale [42] and autecological preferences. Hal-halobity degree on the Hustedt's [43] (hb-oligohalobes-halophobes, i-oligohalobes-indifferent, mh-mesohalobes, hl-halophiles; oh-oligohalobes of whide specter with optimum as indifferent); $\mathrm{pH}-\mathrm{pH}$ degree on the Hustedt's [44] (alb-alkalibiontes; alf-alkaliphiles, ind-indifferents; acf-acidophiles; neu-neutrophiles); S-degree of saprobity on the Pantle-Buck's [45-47] (x-xenosaprobes, x-o-xeno-oligosaprobes, $\mathrm{o}$-x-oligo-xenosaprobes, $\mathrm{x}-\beta$-xeno-betamesosaprobes, $\mathrm{o}$-oligosaprobes, $\mathrm{o}-\beta$-oligo-betamesosaprobes, $\beta$-o-beta-oligosaprobes, $\beta$-betamesosaprobes, $\beta-\alpha \quad$-beta-alphamesosaprobes, $\quad \beta$-p-beta-polysaprobes, $\quad$ - $\alpha$-oligo-alphasaprobes, $\quad \alpha$ - $\beta$-alpha-betamesosaprobes, $\quad \alpha$-alphamesosaprobes, i-i-eusaprobes); Nitrogen uptake metabolism [48] (ats-nitrogen-autotrophic taxa, tolerating very small concentrations of organically bound nitrogen; ate-nitrogen-autotrophic taxa, tolerating elevated concentrations of organically bound nitrogen; hne-facultatively nitrogen-heterotrophic taxa, needing periodically elevated concentrations of organically bound nitrogen; hce-obligately nitrogen-heterotrophic taxa, needing continuously elevated concentrations of organically bound nitrogen); Trophic state [48] (ot-oligotraphentic; o-m-oligo-mesotraphentic; m-mesotraphentic; m-emeso-eutraphentic; e-eutraphentic; he-hypereutraphentic; hy-oligo-to eutraphentic (hypereutraphentic)); ${ }^{*}$-taxa, previously mentioned in references for the Upper Jordan River and tributaries; ${ }^{*}$-first time finding taxa for Israel.

A dendrite (Figure 15), which was constructed by the paar-similarity calculating method, shows the closest cross-sections of the algal communities' diversity in the studied rivers. The bold connection lines of the Upper Jordan, Yehudiyya, and Meshushim rivers revealed the most similar communities. These rivers are very close to each other and to Lake Kinneret. The Daliyyot River community was included in the Upper Jordan River community, and the Banias was included in Yehudiyya.

The Saar and Ayun rivers' communities were included in the Snir community. The Hula and Ram Lakes' communities were not only the most different from the others, but also different between themselves. Ram is a volcanic crater lake and the Hula is a very different type of lake: see dramatic divergence in Figure 15. Therefore, the dendrite revealed the internal relatedness of communities of the rivers. This seems also connected with both hydrology and habitat height above sea level. Species-rich communities from the lower part of the basin were the most similar, and communities of the lakes were most different.

From the results of this investigation of the Upper
Jordan River Basin communities, the species list of algae and cyanobacteria were significantly enriched from 327 to 467 species and infraspecies belonging to seven divisions. We found 232 taxa; 85 were mentioned for the first time for the Upper Jordan River basin and three of which were new for Israel. An historical analysis of the species richness dynamic in the Upper Jordan River algal communities shows that species richness has fluctuated during the last century with peaks in 1951, 1965, 1978, and 2009. Bio-indicators of major fluctuating environmental parameters revealed temperature stress at times when the taxonomic structure was changed - in the 1950s and in 1996. Salinity impacts occurred in 1938 and 2000; acidification in 1938, 1996, and 2000 and organic pollution in 1996. Therefore, we can conclude that 1938, 1996, and 2000 were critical years for the Upper Jordan River ecosystem. As a result, indicators of the trophic status [48] showed the stress of organic pollution since the 1970s, marked by dramatic increases in eutraphentic and hypereutraphentic species.

Present data analyses of spatial distribution of algal communities in the Upper Jordan River can be seen in 




Figure 15. Dendrite of similar taxonomic structure on the rivers of the Upper Jordan basin constructed by the paar-similarity calculating method on the basis of Serensen-Chekanovsky indices. The floristic core of the Upper Jordan River algal diversity is marked by bold lines.

the three peaks of diversity fluctuation. This fluctuation correlates with the impact of organic pollution (revealed by the saprobity indices $S$ ) points on the river channel after the Masade village effluence, after the confluence with three tributaries Snir, Banias and Ayun, and near the entrance to Lake Kinneret (see Figure 1). A significant amount of pollution was from the Masade village area in winter, whereas in the dry summer, the Saar tributary was desiccated. Organic pollution in the central and lower sections of the Upper Jordan basin is found year-round. It dose not damp, but rather stimulates the species diversity. This difference can be reflected in the orientation of each basin area: the Saar tributary is east-west, but the Upper Jordan is north-south. It is important in the arid and semi-arid environments of the Middle East [51].

\section{Conclusions}

The different approaches in comparing the diversity in each river of the Upper Jordan Basin pointed to hydrology as the most regulating factor in species composition of the algal communities. Using comparative floristic methods, we did not reveal any influence of the anthropogenic pollution on the structure of algal communities as a whole. However, it seems that streaming water, which influenced the hydrology of the river, can be marked as having a major impact, as was mentioned for the rivers in the Mediterranean region [52,53]. Dramatic seasonal changes in communities' structure also pointed to hydrology, which was different in dry and rainy seasons, as we revealed for the central Israel riverine communities [10]. On the other hand, the hydrology of the river basin is a conservative factor, which correlates with the climate and topography of the region [4], rather than with the effects of anthropogenic influence (especially for the oligotrophic river, such as the Upper Jordan). Statistical analysis shows indifferent relatedness of the algal species diversity forming process and the anthropogenic pollution influence in the Upper Jordan River Basin as a whole. Our results also show the relatedness to local climatic factors, which controlled species diversity distribution on all diversity levels in the Mediterranean climatic zone [54].

Therefore, since the algal species diversity of the Upper Jordan has been formed under the influence of regional climatic factors, it can be currently recognized as a natural system, with a high buffering and self-purification capacity.

\section{Acknowledgements}

We thank Moti Tavassi for his efforts in collecting algal samples from the Upper Jordan River. This work was partially funded by the Israel Ministry of Absorption and the Ancell Teicher Research Foundation.

\section{References}

[1] A. Dell'Uomo, "Use of Algae for Monitoring Rivers in Italy: Current Situation and Perspectives," In: J. Prygiel, B. A. Whitton, J. Buckowska, Eds., Use of Algae for Monitoring Rivers III, Agence de I'Eau Artois-Picardie Press, Douai Cedex, 1999.

[2] J. Prygiel, M. Coste and J. Buckowska, "Review of the Major Diatom-Based Techniques for the Quality Assessment of Rivers," State of the Art in Europe, In: J. Prygiel, B. A. Whitton, J. Buckowska, Eds., Use of Algae 
for Monitoring Rivers III, Agence de I'Eau ArtoisPicardie Press, Douai Cedex, 1999.

[3] E. Nevo and S. P. Wasser, Eds, "Biodiversity of Cyanoprocaryotes, Algae and Fungi of Israel," Cyanoprocaryotes and Algae of Continental Israel, A. R. G. Gantner Verlag, Ruggell, 2000.

[4] A. Shaban, C. Robinson and F. El-Baz, "Using MODIS Images and TRMM Data to Correlate Rainfall Peaks and Water Discharges from the Lebanese Coastal Rivers," Journal of Water Resource and Protection, Vol. 1, No. 4, 2009, pp. 227-236.

[5] É. Ács and K. T. Kiss, "Investigation of Periphytic Algae in the Danube at Göd (1669 river km, Hungary)," Archive Hydrobiology - Algological Studies, Vol. 62, No. (Suppl. 89), 1991, pp. 47-67.

[6] É. Ács, K. Szabó, K. T. Kiss and F. Hindák, "Benthic Algal Investigations in the Danube River and Some of its Main Tributaries from Germany to Hungary," Biologia, Vol. 58, No. 4, 2003, pp. 545-554.

[7] É. Ács, K. Szabó, B. Tóth and K. T. Kiss, "Investigations of Benthic Algal Community (with Special Attention to Bentic Diatoms) in Connection with Reference Conditions in WFD," Acta Botanica Hungarica, Vol. 46, 2004, pp. 255-278.

[8] É. Ács, K. Szabó, Á. K. Kiss, B. Tóth, Gy. Záray and K. T. Kiss, "Investigation of Epilithic Algae on the River Danube from Germany to Hungary and the Effect of a Very Dry Year on the Algae of the River Danube," Archive Hydrobiology Large Rivers, Vol. 16, No. (Suppl.), 2006, pp. 389-417.

[9] K. É. Szabó, K. T. Kiss, Gy. Taba and É. Ács, "Epiphytic Diatoms of the Tisza River, Kisköre Reservoir and Some Oxbows of the Tisza River after the Cyanide and Heavy Metal Pollution in 2000," Acta Botanica Croatica, Vol. 64, No. 1, 2005, pp. 1-46,

[10] S. S. Barinova, M. Tavassi and E. Nevo, "Study of Seasonal Influences on Algal Biodiversity in the Yarqon River (Central Israel) by Bio-Indication and Canonical Correspondence Analysis (CCA)," Turkish Journal of Botany, Vol. 33, 2009, pp. 353-372.

[11] A. A. El-Awamri, A. E. M. Shaaban and A. I. Saleh, "Floristic Study on Benthic Diatoms of the Groundwater Seepages at Kobri El-kobba (Cairo, Egypt)," Journal of Applied Science Research, Vol. 3, No. 12, 2007, pp. 1809-1818.

[12] L. E. Squires and N. S. Saoud, "Effects of Water Quality and Season on Diatom Community Structure in the Damour River, Lebanon," Hydrobiologia, Vol. 133, No. 1, 1986, pp. 127-141.

[13] Y. Aktan and G. Aykulu, "Colonisation of Epipelic Diatoms on the Littoral Sediments of Üzmit Bay," Turkish Journal of Botany, Vol. 29, No. 2, 2005, pp. 83-94.

[14] H. Gurbuz and E. Kivrak, "Use of Epilithic Diatoms to Evaluate Water Quality in the Karasu River of Turkey," Journal of Environment Biology, Vol. 23, No. 3, 2002, pp. 239-246.
[15] M. Menachem, "The Jordan Valley and Eastern Sumaria," Bikat Hayarden Ve Mizrach Hashomron, Hebrew, 1992.

[16] T. Berman, U. Pollngher and T. Zohary, "A Short History of Stability and Change in Phytoplankton Populations in Lake Kinneret," Israel Journal of Plant Science, Vol. 46, No. 2, 1998, pp. 73-80.

[17] I. Dor, "Algues Des Sources Thermals de Tiberiade, Lake Tiberias Investigations," The Sea Fisheries Research Station Bulletin, Vol. 48, No. 4-5, 1967, pp. 3-29.

[18] I. Dor, "Considerations about the Composition of Benthic Algal Flora in Lake Kinneret," Hydrobioogia, Vol. 44, No. 2-3, 1974, pp. 255-264.

[19] A. Ehrlich, "Atlas of the Inland-Water Diatom Flora of Israel," Israel Academic Science and Human, Vol. 5, 1995, pp. 173-175.

[20] H. Hisoriev, A. F. Krahmalny and L. Krinitz, "Species Diversity of Algae in Water Bodies of Hula Valley (Northern Israel)," Algologia, Vol. 6, No. 2, 1996, pp. 49-56.

[21] H. Hisoriev, S. P. Wasser, E. Nevo and V. V. Stupina, "In Addition to the Flora of Euglenophyta of Israel," International Journal of Algae, Vol. 1, No. 2, 1999, pp. 63-75.

[22] B. Kimor and U. Pollingher, "The Plankton Algae of Lake Tiberias," Sea Fish Research Station of Haifa, ser. A78, Vol. 16, No. 7, 1965, pp. 1-72.

[23] B. Kimor, "The Phytoplankton of Lake Kinneret," Monographiae Biologicae, Vol. 32, No. 1, 1978, pp. 231-233.

[24] B. Komarovsky, "A Comparative Study of the Phytoplankton of Several Fish Ponds in Relation to Some of the Essential Chemical Constituents of the Water," Bulletin Research of Council Israel, Vol. 2, No. 4, 1953, pp. 379-410.

[25] A. F. Krakhmalny, S. P. Wasser and E. Nevo, "New Dinophyta Species for Israel," Algology, Vol. 6, No. 1, 1996, pp. 81-85.

[26] G. M. Palamar-Mordvintseva, "To Flora of Zygnematales (Conjugatophyceae) of Israel," Algologia, Vol. 6, No. 4, 1996, pp. 405-426.

[27] U. Polingher, "The Algae of the River Jordan," Monographiae Biologicae, Vol. 32, No. 2, 1978, pp. 223-228.

[28] U. Polingher, "Algae Found in the Plankton of Lake Kinneret," Monographiae Biologicae, Vol. 32, No. 2, 1978, pp. 236-242.

[29] U. Pollingher, T. Zohary and T. Fishbein, "Algal Flora in the Hula Valley - Past and Present," Israel Journal of Plant Science, Vol. 46, No. 3, 1998, pp. 155-168.

[30] M. Petit, "Liste des Diatomées du Lac de Tibériadé," In: L. Lortet, Ed., Études Zoo-Logiques sur la Fauna du lac de Tibériade suivies dén aperçu sur la fauna des lacs d'Antioche et de Homś," Archieve Museum History Nature (Lyon), Vol. 3, No. 11, 1883, pp. 191-192.

[31] M. Rahat and I. Dor, "The Hidden Flora of a Lake," Hyrobiologia, Vol. 31, No. 2, 1968, pp. 186-192. 
[32] T. Rayss and E. Katchalsky, "About the Plankton in Lake Hula," Country and Nature Brochure, Vol. 5, No. 10, December 1938, pp. 669-671.

[33] T. Rayss, "Materiaux Pour la Flore Algologique de la Palestine I. Les Cyanophycees," Pakistan Journal of Botany, Vol. 3, No. 1, 1944, pp. 94-113.

[34] T. Rayss, "Les Algaes des Aeux Continentals. Materiaux Paur la Flore Algologique de la Palestine," Pakistan Journal of Botany, Vol. 5, 1951, pp. 71-95,

[35] F. E. Round, "The Benthic Algae," In: C. Serruya, Ed., Lake Kinneret, Dr. W. Junk Publishers, Dordrecht, 1978, pp. 323-328.

[36] P. M. Tsarenko, V. V. Stupina, S. P. Wasser, E. Nevo, O. V. Kovalenko, E. S. Kondratiuk, H. H. Hisoriev, A. F. Krahmalny and L. Krinitz, "Species Diversity of algae in Water Bodies of Hula Valley (Northern Israel)," Algologia, in Russian, Vol. 6, No. 2, 1996, pp. 182-193.

[37] E. Swift, "Cleaning Diatom Frustules with Ultraviolet Radiation and Peroxide," Phycologia, Vol. 6, No. 2-3, 1967, pp. 161-163.

[38] S. S. Barinova, "Morphology of Connective Spines in Diatom Algae of the Genus Aulacoseira Thwaites," $\mathrm{Pa}$ leontological Journal, Vol. 31, No. 2, 1997, pp. 239-245.

[39] M. D. Guiry and G. M. Guiry, "AlgaeBase," World-Wide Electronic Publication, National University of Ireland, Galway, December 2009. http://www.algaebase.org

[40] S. S. Barinova, L. A. Medvedeva and O. V. Anissimova, "Diversity of Algal Indicators in Environmental Assessment," Pilies Studio (in Russian), 2006.

[41] E. Lipkovsky, S. Barinova, B. Teltsch and E. Nevo, "Seasonal Influences on Algal Biodiversity in the Upper Jordan River by bioindication and Canonical Correspondence Analysis (CCA)," Applied Ecology and Environmental Research, in Press.

[42] N. V. Korde, "The Methods of Biological Studies for the Bottom Deposits of Lakes (The Field Methods of Biological Analysis)," In: Freshwater Life in USSR, Russion Academic Science Press, in Russian, Vol. 4, No. 1, 1956, pp. 383-413.

[43] F. Hustedt, "Systematisch und Okologische Untersuchungen Uber Die Diatomeenflora von Java, Bali und Sumatra," Archieve Hydrobiology Supply, Vol. 15, pp.
131-177, 393-506, 638-790; Vol. 16, pp. 1-155, 274-394, 1938-1939.

[44] F. Hustedt, "Die Diatomeenflora des Flußsystems der Weser im Gebiet der Hansestadt Bremen," Abhandl Naturw Ver Bremen, Vol. 34, No. 3, 1957, pp. 181-440.

[45] E. Pantle and H. Buck, "Die Biologische Uberwachung der Gewässer und Die Darstellung der Ergebnisse," Gasund Wasserfach, Vol. 96, No. 18, 1955, pp. 1-604.

[46] V. Sládeček, "System of Water Quality from the Biological Point of View," Achieves für Hydrobiologie Beiheft Ergebnisse der Limnologie, Vol. 7, No. 1, 1973, pp. 1-218.

[47] V. Sládeček, "Diatom as Indicators of Organic Pollution," Achieves Hydrochemistry Hydrobiology, Vol. 14, 1986, pp. 555-566.

[48] H. Van Dam, A. Mertens and J. Sinkeldam, "A Coded Checklist and Ecological Indicator Values of Freshwater Diatoms from the Netherlands," Netherlands Journal of Aquatic Ecology, Vol. 28, No. 1, 1994, pp. 117-133.

[49] P. Bourrelly, "Ecology of Freshwater Organisms. 2. Algae and Other Aquatic Plants," Verhandlungen der Internationalen Vereinigung Limnologie, Vol. 18, No. 1, 1973, pp. 1326-1337.

[50] A. B. Novakovsky, "Abilities and Base Principles of Program Module 'GRAPHS'," Scientific Reports, Komi Scientific Center, Ural Division of the Russian Academy of Sciences, Vol. 27, No. 1, 2004.

[51] M. Al Saud, "Watershed Characterization of Wadi Aurnah, Western Arabian Peninsula," Journal of Water Resource and Protection, Vol. 1, No. 5, 2009, pp. 316-324.

[52] B. C. Emerson and R. G. Gillespie, "Phylogenetic Analysis of Community Assembly and Structure over Space and Time," Trends Ecology Evolution, Vol. 23, No. 11, 2008, pp. 619-630.

[53] M. Cantonati, R. Gerecke and E. Bertuzzi, "Springs of the Alps - Sensitive Ecosystems to Environmental Chan- ge: From Biodiversity Assessments to Long-Term Studies," Hydrobiologia, Vol. 562, No. 1, June 2006, pp. 59-96.

[54] T. Pavliček and E. Nevo, "Local Species Richness Distribution at 'Evolution Canyon' Microsite," Mt. Carmel, Israel, Ecologia Mediterranean, Vol. 34, No. 6, 2008, pp. 25-34. 